\title{
THE
}

\section{Psychological Review}

EDITED BY

J. MCKEEN CATTELL COLUMBIA UNIVERSTTY
J. MARK BALDWIN

Princeton UnIVRRSTTY

WITH THE CO-OPERATION OP

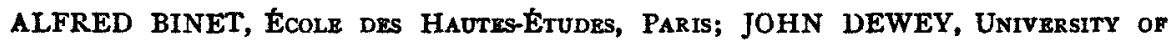
Chicago; H. H. DONALDSON, University of Chicago; G. S. FULlerton,

UNIVERSITY OF PrNNSYlvaNia; JOSEPH JASTROW, UNIVRRSTTY OF WISCONSIN; G. T. LADD, YALE UNIVERSITY; HUGO MUNSTERBERG,

Harvard Universtty; M. Allen STaRr, Colirge of PhySICLANS AND SURGEONS, NEW YORK; CARL STUMPF, UNIVRRSITY, BERLIN; JAMES SULLY, UNIVERSITY College, LoNDON.

Series of Monograph Supplements, Vol. II., No. 3 (Whole No. 7), May, 1898.

\section{Mental Imagery}

Experimentally and Subjectively Considered

BY

WILFRID LAY, A.B.,

Sometnme Unvversity Fellow in Philosophy, Columbia University.

Submited in Partial Fulfilment of the Requirements of the Degree

of Doctor of Philosophy in the Faculty of Philosophy, Department of Psychology, Columbia Untversity.

THE MACMILLAN COMPANY, 4 N. QUEEN ST., LANCASTER, PA. 66 FIFTH AVENUE, NEW YORK; AND LONDON. 



\section{CONTENTS.}

I. Introduction :

(a) Mental imagery compared with imagination . . . 2

(b) " " "6 "6 "6 sensation . . . . . 2

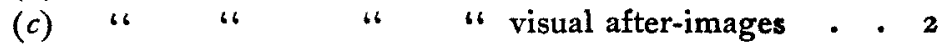

(d) "6 "6 " " memory-images . • . 3

2. Variety of types of mental imagery . . . . . . . . . 4

3. Research and experiment: . . . . . . . . . . 5

Subjective methods. . . . . . . . . . . 5

Objective methods. . . . . . . . . . . . . 6

Experiment $A$. . . . . . . . . . . . 6

Experiment $B$. . . . . . . . . . . . 16

Experiment $C$. . . . . . . . . . . 24

Experiment $D$. . . . . . . . . . . . 29

Experiment $E$. . . . . . . . . . . . $3^{2}$

4. Illustrations of types of imagery in myself . . . . . . . $3^{6}$

5. Word imagery . . . . . . . . . . . . . . . . 40

Slips of the tongue and pen. . . . . . . . . 4 I

Analysis of my word imagery . . . . . . . . $\quad 4^{2}$

6. Historical note on the psychological description of mental imagery . . . . . . . . . . . . . . . . 47

7. Supplementary . . . . . . . . . . . . . . 54 



\section{MENTAL IMAGERY.}

\section{INTRODUCTION.}

Under mental imagery I wish to place not only the images of the so-called five senses, but all the mental representations that are, in part or in entirety, the reflection or 'echo' of the world of sensations. And I would have sensations here include also all the 'internal' sensations and the sensational elements of pleasure and pain.

The terms ' reflection' and 'echo' are but figures of rhetoric and are misleading if taken to mean nothing more than the faint reflection or reproduction, after an interval of time, of something that has happened to us. For in the case of what I shall presently mention under the name of mental imagery of emotion, there is no reason to pre-suppose any individual love, hate or angry feeling of which the emotional mental image is a reproduction. It is a part of the stream of thought, and is to be so regarded in just the same way that visual or auditory or any other imagery is a part of it.

Mental imagery might finally be defined as the content of our mind when we have no sensation but yet are not asleep; when we are alone, in the dark, in complete silence, and oblivious of the chair or bed or bit of ground on which we happen to be sitting, lying or standing.

In this essay no attention will be paid to memory except when it is bringing before the mind the sensations of the past. It is thus an essay on one aspect of memory. Neither will attention be paid to laws of association. Associations have been collected by psychologists from all sides but (as an association is no more than the manner in which thoughts come to the mind, as it is an observed order of events and not an event, the event being the mental imagery) they will not be noticed qua associations at all. 
I. Mental Imagery Distinguished from Imagination. By imagination is here meant the 'faculty' generally called, more specifically, creative imagination. It is that which makes great works of art, whether they be paintings, sculptures, poems, symphonies or cathedrals. The possession of the creative imagination implies that of mental imagery, but not vice versa. Imagination is something abstract and indescribable ; imagery is concrete and experienced by every one. Imagination is something that cannot be itself represented in mental imagery save by a feeling; mental imageries are on the other hand quite as real (not objective, however) as sensations themselves and play quite as important a rôle in our lives.

The association in our minds of the creative imagination with mental imagery is somewhat far fetched from the real nature of things, and is the result of the similarity and like etymology of the English words which are used for these two aspects of mental life. So with imagination as a creative faculty I have nothing to do in this essay.

II. Mental Imagery Distinguished from Sensation. It is almost, if not quite, impossible to draw a line between mental imagery and sensation, as any treatise on illusions and hallucinations will amply demonstrate. On the one hand, illusion becomes so faint as hardly to be known from mental imagery, and on the other, mental imagery is sometimes so strong as to become an illusion. We might, however, make a verbal description limiting mental imagery to those 'subjective sensations' which leave us in no doubt as to their origin, whether internal or external. Where we are in doubt we say it is an illusion.

III. Visual Mental Imagery Distinguished from Visual After-Images. Fechner's well-known distinctions may be summed up as follows: The visual after-images are exact copies (in shape) of the originals; seem unsubstantial, though sharp in outline; feel coercive; cannot be voluntarily changed; are continuously enduring; are bright but almost colorless; are more easily observed with closed than with open eyes; seem to move with the eyes; and have no perspective, being, when the eyes are closed, in a dark, flat and contracted field. The attention seems to be directed forward toward them. The mental imag- 
ery, however, is the direct opposite to this in all ways, according to Fechner. My own repeated experience agrees with his only in the statements which I have italicized. The after-images feel coercive etc., but not more so than do the mental imageries (see pp. 53 and 59). I find also that my attention has no forward or backward in purely visual terms. All my mental imageries are conceived as before my eyes to be sure, but this before has no behind. When visually imagining what is behind me, I always manage to see it before my mind's eye. In other words I see no direction in mental imagery. I can not compare mental imagery and after-images in point of substantiality. They seem to be totally incommensurable.

To me the after-images seem blurred always, there being no sharpness of outline at all. The mental imageries are, on the other hand, sharp in outline, but only in one spot at a time. Otherwise they are as indefinite and incomplete as is actual vision (when one looks at a thing, as one does every day, many times, and does not see it). I never had a visual after-image so large that any part of it was out of the focus of attention when I was looking at any other part of it.

After-images of sensations other than sight have not been adequately recognized in psychological literature. They are in many ways so hard to distinguish from mental imagery that their appearances have never furnished an easy field for investigation. I believe that I have observed in myself what might be called tactual after-images.

If I have auditory after-images it is absolutely impossible to recognize them. It might be that the occasional recurrence of a melody after a concert or an opera, is an auditory after-image, but it has none of the objectivity and constancy of the visual after-images and can no more be compared to them in intensity than can visual mental image be compared with visual afterimages.

IV. Mental Images are not Memory Images. The frequently recurring phenomena, memory images, though they stand about half way between, seem to be nearer to after-images than to mental imagery. I am unable to recall any memory images that have any of the coercive quality of after-images. 
They are usually completely dispelled by a contradictory sensation, $e . g$., the memory image of a pen behind the ear is completely annihilated by putting the hand up and letting the fingers feel that it is not there.

I have sometimes a very strong feeling which seems to be a memory image and yet has otherwise all the marks of a mental image. If a person comes into the room unseen and I hear it, I have a feeling of direction, of approach, of vicinity, of a physical body near (How can it be expressed?), at any rate a definite feeling as if, perhaps, the nerves in that part of my body towards the person were pointing in the direction of the person. All this, though I have not looked around, and there is no visualization in it. Then, if the person leaves the room, the indescribable feeling still continues. As I have observed it in myself it has always continued until I have noticed that there was nobody in the room but myself. Then it completely vanishes. It is a rather unpleasant feeling all through, and if I were not too absorbed I would immediately dispel it by looking around. Sometimes it has lasted for a minute or two.

But whether the image be a memory image or mental imagery seems to depend on our subsequent recognition that the former had an objective stimulus. In such case then the distinction would in this essay be immaterial.

The Variety of Types of Mental Imagery. We have mental imagery from all the senses; that is, some of us are conscious of it. Nobody except the born blind and deaf would deny the existence of visual and auditory mental imagery. Many persons claim to be able to recall the smell and the taste of fruit. A few would recall the "touch of the vanished hand," but I think very few are conscious of all the mental imageries enumerated in the following table, viz. :
I. Visual.
6. Thermal.
2. Auditory.
7. Motor.
3. Tactile.
8. Those of pain (not touch).
4. Gustatory.
9. Organic.
5. Olfactory.
Io. Those of emotion.

These mental imageries have the specific qualities of the senses to which they correspond. To recall the appearance is 
an entirely different experience from recalling the taste of an apple.' To recall the touch of a piece of ice (wet, slippery) is an entirely different image from recalling the temperature (cold) or the appearance of it (white, glistening). The various mental imageries are different also in the amount of pleasure they give (both intensity and extensity). The pleasure of dwelling in the imagination upon a glass of wine or a delectable sweetmeat is of very short duration. I believe it is shorter if it be the taste and smell of it which is contemplated than if it be the look of it.

Research and Experiment in the Field of Mental IMAGERY.

The pure introspection with which each one examines his own mind for the sense elements therein might be called when the results are recorded and tabulated, the subjective method of investigation. In my own case I study the mental imagery in myself and isolate it as much as possible from the outside world. This seems to be the only way to study mental states at first hand and as such will become more and more important as psychologists appreciate more and more the inevitability and authority of direct introspection.

To show how difficult it is, on the other hand, to be absolutely sure whether one's introspection is unconsciously deceived by the knowledge of relations, I would note that one of my mistakes in learning stenography seemed to indicate a latent visualization. Thus in writing the word for apology I wrote an outline ending with $-=$ gy. To the eye, therefore, this outline is, to all intents and purposes, correct, if I suppose myself to have visualized the word ' apology' in Roman type, but - represents the hard sound of $g$, the soft sound of $g$ being given by $/$. So that my inference was that, though I was conscious of mentally hearing the word 'apology' correctly pronounced in my own voice, yet I wrote from a visual rather

1 The sight of a red astrachan used to make my mouth water and cause a sharp and delicious pain in my jaws. It doesn't now, but when a tart apple is suggested and I dwell upon the purely sensuous side of it my mouth seems to feel as if it were watering. 
than an auditory image. It might be argued that what I must have associated with the horizontal heavy stroke while writing the word was the look of ' $g$ ' with which the former is correctly associated and not the sound of '_- which is dissimilar to the sound which I heard in my mind's ear. But though the association was in this case most natural, it was not conscious. I had no visual imagery at the time.

I would call objective methods all questions, bearing upon mental imagery, given by myself to others, both in writing and orally, such as the well-known questions of Galton. Questions I would call direct or indirect as they do or do not ask the subject directly to analyze his own thought stream. The value of all objective methods seems to be less than that of the purely subjective and individual one, as questions are often misunderstood and thoughtlessly answered. Thus such questions as "Can you recall sensations of taste, smell, etc?" have been answered in the affirmative but explained in such a way as to throw doubt on the answer. One of my subjects said he recalled the crisp taste of celery.

The direct question " Have you good visual auditory, mental imagery, etc.?" assumes that the answer is to be given by a trained observer of mental phenomena; and yet it must be put to every one.

The indirect questions "Is there a VI on the face of your watch?" "Which shoe do you put on first?" " How do you fold your hands?" etc., when the subject answers without looking at the objects in question, would seem to help us to infer whether the mental imagery is strong or not and even to what sense it belongs. From the answer to the question about the face of the watch we infer, if the answer is correct, that the person has a good visual imagery, and by the question " How do you fold your hands?" we might elicit whether or not the motor or tactile imagery is good.

\section{Experiment $A$.}

Among these indirect questions is also included the experiment which $I$ have made upon roo juniors (2 classes, ' 96 and '99) in Columbia College. I have read aloud to them a short 
passage (translation) from a French novel, which took about a minute to read and which, as I believe, contained words likely to arouse in the minds of the hearers the mental images most noticeable in our every day life, $i . e$., those of sight and sound. The words aroused in me a certain number of mental images which I could specify and record, and I supposed that others would have the same aroused. This, of course, does not necessarily follow but it seems likely. Then the juniors were asked to write down all they could remember of the passage, whether in the same words or not. From the number of words written down by them which (to me) suggested mental images I compiled a table which showed what per cent. of visual and auditory images had been recalled. This supposed that what was recalled would be the easiest and that the easiest to remember for each one would be that which most corresponded with the tendency of his mind. If he was eye-minded he would naturally remember the visual elements of the description; if he was earminded he would naturally recall the auditory elements. This experiment I call an indirect question, because it attempted, by means of the memory, though hampered by the memory's imperfections, to ascertain whether the mind worked in terms of one sense more than another and, if so, how much more. Answers to this particular question were quite satisfactory in some ways. The results were large. A hundred answers to it could be gotten in 15 minutes; and the matter could be very easily tabulated and a statement made with some show of authority that "You have $76 \%$ visual and $20 \%$ auditory" or "You have $80 \%$ visual and $15 \%$ auditory."

But though indirect questions are likely to be better understood, and are more to be relied upon than the direct questions, I think that the experiment just described, and indirect questions like it, are open to several important objections. In the first place, in a given number of words there is not a definite and constant number of visual or other images, because the imagery belongs not to the word so much as to the person, and I myself might have more or less than others. In the second place, in an experiment which involves the memory even for the space of one minute, a complete register of the mental imagery of each student is hardly to be expected. 
As a test for the mental imagery I gave the same blank to students (52) that I gave to artists (p. 16) and supplemented the blank in the case of students (IOO) by the following. I said: "I will now read to you a translation from the French of Flaubert, after which I wish you would write out as much of it as you remember, and then try to describe how you remembered it, whether by the words or by the visual or other images that are called up :

"She always went with him to the first step of the outside stairs. If his horse had not yet been brought forward they remained there. They said good-bye; they attempted no further remark; the fresh air encompassed her, played with the downy hair of her neck or blew about her side the strings of her apron which twisted and twirled like a little fag. Once, when a thaw had set in, the water was trickling down from the bark of the trees and the snow was melting from the roofs of the buildings. She stood on the threshold; she went back to get her parasol; she opened it. The parasol was of a changeable green and blue silk and the sun shining through it lent a radiant and flickering lustre to her white complexion. She smiled beneath it while the soft zephyrs played about her and the raindrops were heard to come pattering down one by one on the outstretched silk of the parasol."-Madame Bovary.

They were allowed ten minutes to write what they remembered of this, after which I read to them an extract from Bain, making the same requests as before concerning it :

"The subject-matter of geometry embodies a few fundamental notions and processes. A definition, an axiom, a postulate, a proposition, whether theorem or problem, a chain of demonstration, are to the beginner things absolutely new; they must be fixed by the plastic power of contiguity; and time and concentration must be allowed for the purpose. But in a good head one or two examples of each, strongly imprinted, will make the rest easy ; the method or character of the devices will be seen through and acquired and in every new case the mind will fall back upon the old ones for the common element, and concentrate attention upon the points of difference solely. When, after going over a few definitions, the learner is impressed with the form and peculiarity of a definition, there is little to acquire in the rest : a slight substitution serves to make a new one out of an old; the definition of a square is easily changed to suit a rectangle."

It is to be noted here that these two extracts differ one from the other in the following respects :

In the first there are 166 words only 72 of which are words that arouse imagery from one of the 'five senses.' There are two ${ }^{1}$ such words occurring twice and one ${ }^{2}$ that occurs three times.

There are 7 unusual words : encompassed, twirled, trickle, radiant, fickering, lustre, zephyrs.

1 Play, silk.

${ }^{2}$ Parasol. 
There are $\mathrm{I} 3$ words with few (or no) synonyms, viz, went, stairs, horse, apron, strings, flag, thazw, snow, green, blue, silk, sun, smiled.

In the second there are 165 words, only 70 of which arouse imagery from one of the 'five senses.' There are six such words occurring twice (concentrate, few, acquire, rest, new, old) and one which occurs four times (definition). Two have words so nearly like them that the image would be the same (concentrate $=$ concentration ; impressed=imprinted).

There are two unusual words: plastic, contiguity.

There are six words with few (or no) synonyms; axiom, postulate, new, old, definition, square.

In the first extract the word raindrops is misleading. It is evidently a slip of the translator and it resulted in a large per cent. of the subjects affirming that it was raining and five per cent. using the word ' umbrella' instead of 'parasol.'

The first extract can be arranged into eleven periods, each of which may be regarded as a visual (or auditory) unit; and each one taking as long to read aloud (in my own case, at any rate) as a visual mental image naturally and usually remains before the mind's eye. There is also some change in the picture for each new period.

The second extract seems to proceed in like manner step by step, and to be divisible into ten periods, at the end of each of which one can pause with the feeling of a step taken. Possibly it is this feeling which is most frequent in reading a book on any abstract subject. As I read the quotation from Bain I go through a sort of undulation (so to speak) of feeling. At the beginning of the clause I am straining my attention, and at or near the end of it, having ' grasped the meaning' of the author, an immediate feeling $(A)$ of "Yes, that is so," or $(B)$ " No, it isn't," supervenes, and I go on to the next sentence. Sometimes the "Yes, that is so" feeling is so strong that I am moved to underscore the phrase or score the margin of the page, or if the "No, it isn't," feeling, that it is inconsistent with itself or with my own experience of life, is very strong, I write out the clause on a piece of paper, in order to get the feeling of $(C)$ ' reviewed 'or 'passed muster.' If I do not, I have the feel- 
ing of $(D)$ 'omission,' and am not satisfied with my perusal. In this manner, as I read the book or the paper the feelings $A$, $B$, and $C$ or $D$ continue to follow one another.

None of the periods of the extract from Bain is capable of being represented by mental imagery from the five senses, in any form (visual, etc.) but is represented or accompanied by feelings which are similar to mental imagery in their faintness and obscurity. The words of the extract are represented in my mind only by the mental imagery of them qua words heard, and by the faint feelings just noted, which I should like to call mental images.

The accompanying Table I. shows in column I. the 72 words or phrases into which I have divided the first extract. Each of these, I infer, contains one idea which either is a mental image (from one of the 'five senses') or is a feeling of relation, and in the memory is revived (as one or the other of these) before being put into words. In column II. are given the numbers (out of 100) of the words correctly reproduced by the subject. In column III. are the ideas correctly remembered but expressed in words different from those of the extract. In column IV. are the total number of ideas correctly reproduced. $E$. $g$., for phrase 43,70 men out of the Ioo wrote parasol, 4 wrote umbrella, thus 74 remembered the $i d e a$; and 26 said nothing about any kind of protection from either sun or rain.

In the $\mathrm{V}$. column the totals for the eleven groups are given, and in column VI. are given the per cent. of the groups. Thus in group (a) 333 ideas were reproduced out of a possible 600 , or, as column VI. shows, $55.5 \%$. Column VI. shows also that the group which was best remembered was, however, group (b), 'If his horse,' etc., and that next to it came group $(g)$, "She went back to get her parasol "-both short sentences-after which came group ( $i)$, "The parasol was changeable," etc. It is interesting to note, however, that the per cent. of the words "The parasol was changeable green and blue silk, and the sun shining," would be $49 \%$. So that it may be said that all that was remembered by about half the men was "She always went with him to the first step of the outside stairs. If his horse had not been brought forward they remained there. She went back to get 
Flaubert.

BaIN.

\begin{tabular}{|c|c|c|c|c|c|c|c|c|c|c|c|c|c|}
\hline & I & 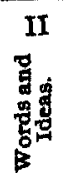 & III & 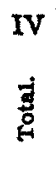 & $\begin{array}{l}v \\
\text { gov } \\
\text { gog }\end{array}$ & $\begin{array}{l}\text { VI } \\
\text { ه }\end{array}$ & & VII & 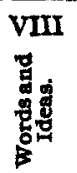 & $\begin{array}{l}\text { IX } \\
\\
\text { : }\end{array}$ & 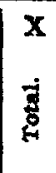 & 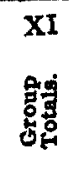 & $\begin{array}{l}\text { XII } \\
\text { 。o }\end{array}$ \\
\hline (c) & $\begin{array}{l}\text { I she went } \\
2 \text { always } \\
3 \text { with him } \\
4 \text { to the first steps } \\
5 \text { of the stairs } \\
6 \text { outside } \\
7 \text { if his horse } \\
8 \text { brought forward } \\
9 \text { they remained } \\
\text { 10 they said good bye } \\
\text { II they attempted } \\
12 \text { no further } \\
13 \text { remark } \\
14 \text { the fresh } \\
15 \text { air } \\
16 \text { encompassed her } \\
17 \text { played with } \\
18 \text { the downy } \\
\text { 19 hair } \\
20 \text { of her neck }\end{array}$ & $\begin{array}{r}64 \\
54 \\
53 \\
47 \\
35 \\
31 \\
69 \\
32 \\
22 \\
44 \\
10 \\
11 \\
8 \\
3 \\
15 \\
13 \\
42 \\
34 \\
65 \\
39\end{array}$ & $\begin{array}{r}3 \\
3 \\
26 \\
5 \\
0 \\
36 \\
2 \\
3 \\
7 \\
7 \\
5\end{array}$ & $\begin{array}{r}47 \\
13 \\
37 \\
13 \\
3 \\
51 \\
15 \\
45 \\
41 \\
72 \\
44\end{array}$ & $\begin{array}{l}\text { (b) } \\
\text { 175 }\end{array}$ & $5^{8.3}$ & $(\mathrm{~m})$ & $\begin{array}{l}\text { I the subject matter } \\
2 \text { of geometry } \\
3 \text { embodies } \\
4 \text { a few } \\
5 \text { fundamental } \\
6 \text { notions } \\
7 \text { and processes } \\
8 \text { a definition } \\
9 \text { an axiom } \\
\text { 10 a postulate } \\
\text { I1 a proposition } \\
12 \text { theorem } \\
\text { I3 problem } \\
\text { I4 chain } \\
15 \text { of demonstration } \\
16 \text { are to the beginner } \\
\text { 17 things absolutely new } \\
\text { 18 they must be fixed } \\
19 \text { by the plastic } \\
20 \text { power }\end{array}$ & $\begin{array}{r}18 \\
79 \\
16 \\
9 \\
29 \\
3 \\
11 \\
49 \\
75 \\
60 \\
32 \\
25 \\
7 \\
6 \\
4 \\
26 \\
14\end{array}$ & $\begin{array}{l}0 \\
0 \\
I \\
0 \\
0 \\
0 \\
1 \\
2 \\
4 \\
4\end{array}$ & $\begin{array}{r}49 \\
75 \\
61 \\
32 \\
25 \\
7 \\
7 \\
6 \\
30 \\
18\end{array}$ & $\begin{array}{c}(\mathrm{m}) \\
3^{10}\end{array}$ & 25.5 \\
\hline
\end{tabular}


Flaubert.

BAIN.

\begin{tabular}{|c|c|c|c|c|c|c|c|c|c|c|c|c|c|}
\hline & I & 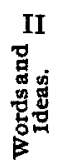 & 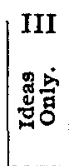 & 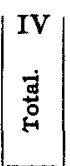 & 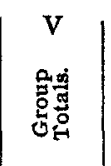 & $\begin{array}{l}\text { VI } \\
\text { ஃீ }\end{array}$ & & VII & 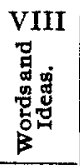 & 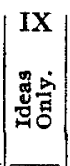 & 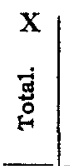 & 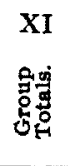 & $\begin{array}{l}\text { XII } \\
\curvearrowright\end{array}$ \\
\hline (g) & $\begin{array}{l}21 \text { blew about } \\
22 \text { her side } \\
23 \text { the strings } \\
24 \text { of her apron } \\
25 \text { which twisted } \\
26 \text { and twirled } \\
27 \text { like a flag } \\
28 \text { little } \\
29 \text { once a thaw } \\
30 \text { had set in } \\
31 \text { the water } \\
32 \text { was trickling } \\
33 \text { from the bark } \\
34 \text { of the trees } \\
35 \text { and snow } \\
36 \text { was melting } \\
37 \text { from the roofs } \\
38 \text { of the buildings } \\
39 \text { she stood } \\
40 \text { on the threshold } \\
41 \text { she went back }\end{array}$ & $\begin{array}{r}23 \\
3 \\
27 \\
45 \\
6 \\
4 \\
22 \\
16 \\
27 \\
10 \\
10 \\
23 \\
31 \\
25 \\
37 \\
22 \\
24 \\
30 \\
4 \\
5 \\
6 \\
36\end{array}$ & $\begin{array}{r}14 \\
I \\
2 \\
I \\
I \\
I 3 \\
I \\
I \\
8 \\
8 \\
5 \\
5 \\
I 4 \\
4 \\
0 \\
2 \\
I \\
4 \\
4 \\
I \\
2\end{array}$ & \begin{tabular}{|r|}
37 \\
4 \\
29 \\
46 \\
7 \\
17 \\
23 \\
17 \\
35 \\
15 \\
28 \\
45 \\
29 \\
37 \\
24 \\
25 \\
34 \\
8 \\
6 \\
8
\end{tabular} & $\begin{array}{l}\text { (d) } \\
4^{14}\end{array}$ & 57.6 & (q) & $\begin{array}{l}21 \text { of contiguity } \\
22 \text { and time } \\
23 \text { and concentration } \\
24 \text { must be allowed } \\
25 \text { for the purpose } \\
26 \text { but in a good head } \\
27 \text { one or two } \\
28 \text { examples } \\
29 \text { of each } \\
30 \text { strongly } \\
31 \text { imprinted } \\
32 \text { will make easy } \\
33 \text { the rest } \\
34 \text { the method } \\
35 \text { or character } \\
36 \text { of the devices } \\
37 \text { will be seen through } \\
38 \text { and acquired } \\
39 \text { and in every case } \\
40 \text { new } \\
41 \text { the mind }\end{array}$ & $\begin{array}{r}20 \\
5 \\
13 \\
2 \\
0 \\
9 \\
5 \\
4 \\
1 \\
2 \\
5 \\
7 \\
5 \\
0 \\
0 \\
2 \\
0 \\
0\end{array}$ & $\begin{array}{l}4 \\
0 \\
\mathrm{I} \\
\mathrm{I} \\
\mathrm{I} \\
5 \\
6 \\
0 \\
0 \\
4 \\
7 \\
7 \\
0 \\
0 \\
0 \\
2 \\
2 \\
6 \\
0 \\
2 \\
0\end{array}$ & $\begin{array}{r}24 \\
5 \\
14 \\
3 \\
1 \\
14 \\
11 \\
4 \\
1 \\
6 \\
12 \\
14 \\
5 \\
0 \\
0 \\
4 \\
2 \\
6 \\
0 \\
3 \\
7\end{array}$ & $\begin{array}{l}\text { (0) } \\
67\end{array}$ & 2.4 \\
\hline
\end{tabular}


Flaubert.

BAIN.

(h)

42 to get

43 her parasol

(i)

44 she opened it

45 the parasol

${ }_{4} 6$ was changeable

47 green

48 blue

49 silk

50 and the sun

51 shining

52 through it

53 lent

54 a radiant

55 and flickering

56 lustre

57 to her white

(j) $5^{8}$ complexion

59 she smiled

60 beneath it

6 I the soft

62 zephyrs

\begin{tabular}{|c|c|c|c|c|c|c|c|c|c|c|c|}
\hline 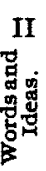 & 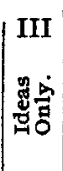 & IV & 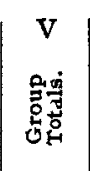 & $\begin{array}{l}\text { VI } \\
20\end{array}$ & & VII & 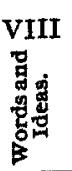 & 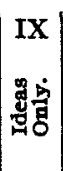 & $\begin{array}{l}\mathbf{X} \\
\stackrel{\vec{J}}{0}\end{array}$ & 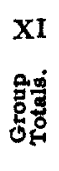 & $a^{\circ}$ \\
\hline 33 & 14 & 47 & & & & 42 will fall back & $\mathbf{I}$ & 7 & 8 & (q) & \\
\hline 70 & 4 & 74 & & & & 43 on the old ones & $\mathbf{1}$ & 4 & 5 & & \\
\hline 22 & 6 & 28 & (h) 28 & 28 & & $\begin{array}{l}44 \text { for the element } \\
45 \text { common }\end{array}$ & $\begin{array}{l}1 \\
2\end{array}$ & $\begin{array}{l}0 \\
2\end{array}$ & $\begin{array}{l}I \\
4\end{array}$ & 28 & $4 \cdot$ \\
\hline I8 & 5 & 23 & & & (r) & 46 and concentrate & o & 2 & 2 & & \\
\hline $\begin{array}{l}54 \\
60\end{array}$ & $\begin{array}{l}2 \\
7\end{array}$ & $\begin{array}{l}56 \\
67\end{array}$ & & & & $\begin{array}{l}47 \text { attention } \\
48 \text { solely }\end{array}$ & o & 0 & 0 & (r) & \\
\hline $\begin{array}{l}34 \\
52\end{array}$ & $\begin{array}{l}0 \\
\mathbf{I}\end{array}$ & $\begin{array}{l}34 \\
53\end{array}$ & & & (s) & 49 upon difference & 8 & 2 & 10 & 17 & 4.25 \\
\hline 35 & 9 & 44 & & & & 5o when after going over & o & I & $\mathbf{I}$ & & \\
\hline 35 & 5 & 40 & (i) & & & $5^{1}$ a few & 3 & $\mathbf{I}$ & 4 & & \\
\hline 28 & 2 & 30 & $4^{66}$ & 33.2 & & 52 definitions & 3 & $\mathbf{0}$ & 3 & & \\
\hline 12 & 9 & 21 & & & & 53 the learner & 0 & $\mathbf{I}$ & $\mathbf{I}$ & & \\
\hline 8 & 2 & 10 & & & & 54 is impressed & 2 & $\mathbf{I}$ & 3 & (s) & \\
\hline 4 & 8 & 12 & & & & 55 with the form & 3 & 5 & 8 & & \\
\hline 7 & 25 & $3^{2}$ & & & & $5^{6}$ and peculiarity & o & I & $\mathbf{I}$ & 29 & 2.6 \\
\hline 25 & I I & $3^{6}$ & & & & 57 of a definition & $I$ & $\mathbf{I}$ & 2 & & \\
\hline 28 & $I_{4}$ & $4^{2}$ & & & & $5^{8}$ there is little & 2 & 3 & 5 & & \\
\hline 5 & o & 5 & & & & 59 to acquire & 0 & 2 & 2 & & \\
\hline 4 & 6 & 10 & & & $(t)$ & & & 0 & 0 & & \\
\hline 3 & $\mathbf{o}$ & 3 & (j) & & & 6r a slight & 5 & 2 & 7 & & \\
\hline I3 & 6 & 19 & $5^{2}$ & 8.6 & & 62 substitution & 8 & $\mathbf{5}$ & 13 & & \\
\hline
\end{tabular}


Flaubert.

BAIN.

\begin{tabular}{|c|c|c|c|c|c|c|c|c|c|c|c|c|c|}
\hline & $I$ & 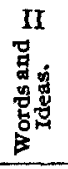 & $\mid \begin{array}{l}\text { III } \\
\text { 总 } \\
\text { 究。 }\end{array}$ & 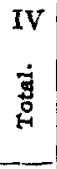 & 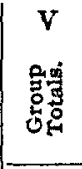 & $\begin{array}{l}\text { v1 } \\
20\end{array}$ & & VII & 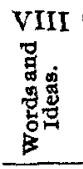 & 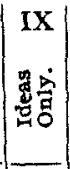 & $\begin{array}{c}\mathbf{X} \\
\dot{\vec{g}} \\
\stackrel{\overrightarrow{0}}{\mathrm{H}}\end{array}$ & 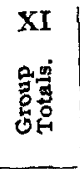 & $\begin{array}{l}\text { XII } \\
\text { o }\end{array}$ \\
\hline (k) & $\begin{array}{l}63 \text { played } \\
64 \text { about her } \\
65 \text { and raindrops } \\
66 \text { were heard } \\
67 \text { to come down } \\
68 \text { pattering } \\
69 \text { one by one } \\
70 \text { on the outstretched } \\
71 \text { silk } \\
72 \text { of the parasol } \\
\text { Totals }\end{array}$ & $\begin{array}{r}8 \\
5 \\
40 \\
11 \\
6 \\
26 \\
5 \\
5 \\
13 \\
18\end{array}$ & $\begin{array}{r}2 \\
0 \\
5 \\
0 \\
17 \\
7 \\
3 \\
5 \\
1 \\
4\end{array}$ & $\begin{array}{r}10 \\
5 \\
45 \\
11 \\
23 \\
33 \\
8 \\
10 \\
14 \\
22\end{array}$ & $245^{8}$ & 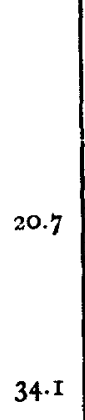 & (u) & $\begin{array}{l}63 \text { serves to make } \\
64 \text { a new one } \\
65 \text { out of an old } \\
66 \text { the definition } \\
67 \text { of a square } \\
68 \text { is changed } \\
69 \text { easily } \\
70 \text { to suit } \\
71 \text { a rectangle }\end{array}$ & $\begin{array}{r}2 \\
6 \\
5 \\
49 \\
52 \\
37 \\
40 \\
16 \\
59\end{array}$ & $\begin{array}{r}2 \\
3 \\
1 \\
0 \\
0 \\
13 \\
9 \\
13 \\
2\end{array}$ & $\begin{array}{r}4 \\
9 \\
6 \\
49 \\
52 \\
50 \\
49 \\
29 \\
61\end{array}$ & $\begin{array}{l}(u) \\
290\end{array}$ & 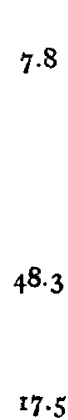 \\
\hline
\end{tabular}


her parasol of changeable green and blue silk and the sun shone through it."

In columns VII.-XII. are given the same statistics for the extract from Bain as were given for that from Flaubert. It will be seen that only about half as much of Bain was remembered as of Flaubert. In this all that was remembered by more than $25 \%$ of the men was that " The subject matter of geometry embodies a few fundamental notions and processes; a definition, an axiom, a postulate, a proposition, whether theorem or problem, are to the beginner things absolutely new. The definition of a square may be easily changed to suit a rectangle." The rest of the extract will be seen to have impressed only from $2.6-9.5 \%$ of itself upon the hearers. I think the total and total per cent. for this passage would have been less, too, had it not terminated with the very definite statement concerning quite familiar concepts which it did.

As to the mental imagery involved, in the memory of the foregoing passages, it is necessary to note the following: Aside from the evident adaptability of the extract from Flaubert to an easy visual resuscitation, and the obvious difficulty in representing that from Bain in any sense imagery, except the auditory imagery of the words themselves, both of which characteristics are fully shown in the statistical results of the experiment, it will be seen that the visual mental imagery is more commonly the form in which the reproduction takes place, and that where the visual is not awakened the auditory comes in to help. ${ }^{1}$ The auditory resuscitation includes, of course, both sounds and words. There was in the Flaubert only one purely auditory image called up besides those of the words themselves, viz.: "The rain-drops were heard to come pattering down, one by one, on the outstretched silk of the parasol."

In group $n$ (Bain) the only words which were above the average were plastic, contiguity and concentration, and the first two of these, at least, were uncommon words, and have a peculiarly scientific and philosophical sound. It was certainly the sound rather than the sense of the word which caused one man

${ }^{1}$ Corroborating the results of Jonas Cohn, Bigham, Müller and Schumann, etc. 
to write 'continuity' instead of 'contiguity.' In several cases these words were put down without being made into a sentence, which seems also to corroborate the supposition that the words were remembered as auditory or motor images.

\section{Experiment $B$.}

My most extensive research was among I25 well-known painters and sculptors of New York City, to find what part the conscious visualization played in their work. I found not only that there is no very extraordinary power among these artists, to visualize things more vividly than among ordinary people, but that some painters seem to have the imagery developed but little. Almost the only notable exception is a very well-known artist who paints pictures of rural life with almost photographic fidelity to detail. He told me that he studies and constantly employs his visual mental imagery in painting, constantly referring to it in the manner of Wm. Blake, the English visionary.

I sent these artists a 'Mental Imagery blank,' containing eight questions, the first four taken from Galton, ${ }^{1}$ the last four being Professor Cattell's.

The results of this research as answers to the blank are to be summarized as follows :

To question 1. Think of some definite object, suppose it is your breakfast table as you sat down to it this morning, and consider carefully the picture that rises before your mind's eye.

Are the outlines of the objects distinct and sharp?

$\begin{array}{lr}\text { Yes. } & 50 \% \\ \text { Fairly. } & 11 \% \\ \text { Yes. (Of things drawn.) } & 1 \% \\ \text { Distinct, not sharp. } & 4 \% \\ \text { No. } & 33 \%\end{array}$

To question 2. Are the colors bright and natural?

Exactly as in nature.

Yes.

No.

Subdued.

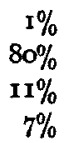

Inquiries into Human Faculty, p. 378 . 
To question 3. Where does the image seem to be situated?

Behind the head.

Impossible to say.

In the head.

Before the eyes.

At a distance.

I\%

$2 \%$

$20 \%$

Exact original distance.

$40 \%$

$22 \%$

$16 \%$

To question 4. How does the size of the image compare with the actual size of the scene?

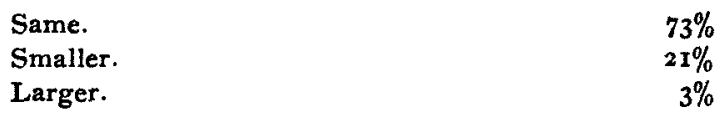

To question 5. Can you call to mind better the face or the voice of a friend?

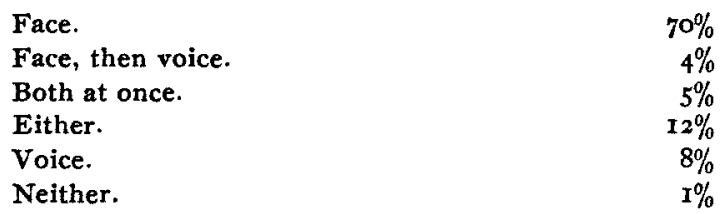

To question 6. When violin is suggested, do you first think of the appearance of the instrument or the sounds made when it is played.
Appearance.
Sound.
$80 \%$
$20 \%$

To question 7. (a) Can you call to mind natural scenery so that it gives you pleasure? (b) music? (c) fruit?

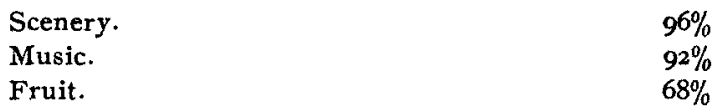

To question 8. Have you ever mistaken an hallucination for a perception?

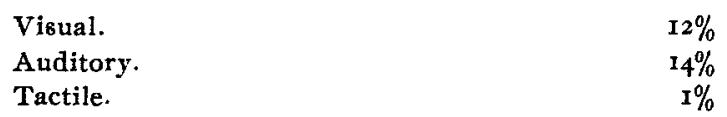

I received many letters from the artists besides the answers to the blanks. These contained much light upon the latter, in most cases corroborating, but in one or two cases contradicting (unconsciously) the statements in the answers to the printed questions. 
Most interesting are several in which the writers describe the way in which ideas for pictures come to them. Says one :

"My impressions have at times been so strong and the location so immediately behind my head that the impulse has been great to turn around to see the scene or figure. When an inspiration or design for a composition comes to me, though my head may be bent forward upon my hands, the image is back of the head or more properly above it and often so distinct that I have drawn out the entire plan of composition with eyes closed."

Says another: "I myself seldom paint from memory, but when occasion occurs I find I can quite readily carry in my mind for several days and in some cases for years a very true impression of a scene. Some artists do this altogether and never employ models. Of course, to do this one must study the scene with the object in view of carrying it in the memory. Take for instance a subject that I studied three years ago with the intention of painting it. I was crossing the river in a ferry boat and, sitting here in my room now as I recall the subject, the room about me seems to vanish and I see before me the river at twilight, dark and full of movement, the sky just correct in value compared with the river and with sundry yellow streaks at the horizon. In the immediate foreground a slender figure leaning somewhat over the rail of the boat. The objects in the boat are all in their place-anchor, bucket, etc., and there are several red and white lights on the Jersey shore."

Says another: "I not only remember the table with the people, dishes and general detail, but the background as well. For years I have practiced the idea of Robert Houdin and his brother of taking [in] or studying an object in as short a time as possible with the eye, then turning away and either drawing or describing it. I remember once making a small oil picture of a city house for a lady who constantly sat at her window and who would have noticed me if she had seen me stop to even make a note. * * By walking slowly by on the opposite side, not more than three different times I made a carefully detailed picture, it being a corner house with some odd buildings in the background made it a little more difficult of course to re- 
call, but each morning as I passed I looked the object carefully over, repeating or speaking to myself the detail from cornice to stoop and so on."

Another writes : "I spent two months at the World's Fair making careful and elaborate pictures of the buildings and various views. This winter I have been enlarging those pictures in my studio and have frequently noticed myself in that state of feeling as of being actually back at Chicago and in the original spots where the various pictures were made-at times the same airs of the bands and cries of the vendors of catalogues, etc., recurring to me."

A sculptor writes: "From my experience in thinking out ideas to illustrate certain given subjects I have frequently seen the imaginative subject so realistically developed as to startle and shock my nervous system. I can only think out subjects, however, to perfection in the dark, preferably in bed-the subjects generally appearing some distance away when clearly developed."

A painter well known for his mural decorations: "Personally, I would say that this image as conceived is rather hazy *** and while there is the sense of seeing it, I seem to feel it quite as much because the personality of a figure so conceived as existing has to me characteristics as well as clothes. If it is an idea involving many figures it is always limited to a very narrow field in which the central or keynote of the composition is more or less suggested. It is on this that work is begun, resting content to allow the actual result as attained on canvass or paper [to?] stimulate the mind to further developments. It may be on this account, perhaps, that the first third of the picture under way moves along rapidly and with few hitches, while the second becomes involved with labor and annoyance and the last third is almost constant irritation and disgust."

Another writes: "As he (the true artist) paints in his studio, without once referring to an out-of-door sketch, far better than the imitator, he must in some way retain a very perfect impression. I can assure you, however, he does not keep one eye on a mental picture while painting. He looks and sees only the canvass, and that, as he will tell you, "feels' right or wrong." 
And another: "In calling up a mental picture of a scene I seem to see objects at the same distance, of the same size and in the same light as they were in reality. They seem to surround me as they did in fact. The image is not definite. Even when it seems to my mental vision tolerably complete the instant an attempt is made to draw from it $I$ find it utterly vague with great unfilled gaps. To reproduce a view once seen is much more an effort of memory than of calling up a mental image. For instance, if I remembered that there were flowers on the breakfast table, I should at once place them in my mental image, but I should hardly see them in the mental image and so remember that they were on the table. Even if my recollection were incorrect and there were no flowers, I should probably call them up and add them to my mental picture if I thought they were there."

And another: "In composing or imagining pictures [I] can call to mind objects more readily with my eyes closed. Even getting at the drawing, foreshortening, etc., with tolerable exactness. For instance, sitting with the eyes closed and thinking very hard of the subject I wish to paint, the picture appears as framed and hung in a gallery. Thus I can make a sketch almost as correctly as though I were doing it from memory after actually seeing a picture.

A pertinent comment upon the question concerning the violin is found in the following words of a very well-known genre and mural painter : "I answer ' the appearance.' It would be more accurate to say the form and the form as seen in certain positions which I have studied for the decorative beauty of the line. But of many other instruments I should say the contrary. - Trumpet,' for instance, expresses sound to me and so do ' horn' and 'flute.' A trombone is so grotesque in its method of operation that that fact occurs to me first. A harp is a decorative form. Of course a lyre is a mere form to all of us. We have never heard it. I think these instances show that association plays a great part in determining our way of imagining things. Also the word violin would have an entirely different effect on me if used in a sentence dealing with a piece of music. Then I should think of its nasal singing." 
In addition to these answers and the letters of explanation sent me at the same time $I$ have a great deal of material bearing upon the mental imagery of artists in the shape of reports of personal interviews. I called upon about twenty-five artists in their studios and put questions to them orally, in this way endeavoring to corroborate the results given by the blanks. I carried a little notebook with me, in which were the following questions, for which, where they are not Galton's questions, I am largely indebted to Professor Cattell :

"I. Does your train of ideas when it proceeds without external stimulation go on in terms of sights, sounds, etc., or words? If words, are they heard words, impulses to articulate or what?

"2. What class of sensations do you most easily recall?

" 3 . Tell me something more at length about the (a) illumination; (b) definition and (c) coloring of your mental imagery.

"4. Does your mental imagery seem to embrace a greater extent of view than the external visual field?

" 5. At what distance do the mental images seem to be?

"6. Have you good command over your mental imagery; e.g., can you make your mental image of a person appear to sit down or walk about?

" 7 . Do you recall the appearance of persons with whom you are familiar better than that of others?

" 8 . When reading a book do you mentally illustrate descriptions of natural scenery, etc.

"9. Have you any peculiar preferences for, or associations with, colors?

" "Io. Is your mental imagery fainter now than in childhood?

"II In terms of what sense is your present recollection of a play or an opera?

"12. Does poetry appeal to you as pictorial?

"13. Do you paint from memory?

"14. Do you recall the sounds of nature?

"15. Do you recall music?

"16. Do you think of the name of an object when it is presented to you? of a person when you meet him?

" 17 . When you read to yourself do you seem to hear any one's voice saying the words? Your own voice or the author's if you happen to know it? When you come to printed italics does this voice seem more intense?

" 18 . Do you rely upon mental words when doing sums in arithmetic? In writing do you spell out every word, seeming to see or hear the letters individually as you write them?

"rg. Do you think in any language other than English? If so, in heard words, impulses to articulate or what?

"20. Do you think the expression 'hear yourself think' would describe your mental state at any time? Do loud noises interfere with your work?

"22. Can you think the word 'bubble' with open mouth. (Stricker and James.) 

ance?

"23. When Apple is mentioned do you think of the taste or the appear-

"24. Have you mental imagery of the following: Tastes: salt, sugar, lemon, raisin. Smells : tar, roses, lamp, hay, violets. Touches : velvet, silk, soap, sand? Heat, cold, hunger, thirst ?

" 25 . Do you become seasick? Could you make yourself seasick by imagining the rolling of a steamer, etc.? Do you become dizzy when at a great height? Can you make yourself dizzy by imagining yourself on a frightful precipice?

"26. Can you imagine a violent movement without the impulse to make it? e. $g$., mentally fire off a pistol without in reality catching your breath, or mentally ride horseback without in reality pressing your knees together just a little? to day?

“"27. Does the emotional background of your consciousness vary from day

As a rule I called upon only one artist a day and took the first opportunity after leaving his studio to record in my notebook exactly what had been said.

Statistical results from the oral questioning just described are almost impossible to collate. I have made, however, an extensive table of the results, which I will attempt partially to summarize.

That these questions were in one or two cases almost tautological with others will not, I think, detract from the value of the answers, but quite the contrary. I should have been better satisfied if I had had the time to put the questions in as many forms as I could think of, to every artist. I felt somewhat diffident, however, about questioning them with too great prolixity. I take pleasure here in thanking them for their uniform courtesy in giving me so much of their time and attention.

Out of 25 artists orally examined by me, 20 said their train of thought went on in scenes, pictures, etc., and 20 said that the sensations most easily and vividly recalled were those of sight. One of these, however, a sculptor, put the vividness of his sense representations in this order: Touch, organic sensations, sounds and sights.

Fourteen of the twenty-five said they had no greater field of mental than of physical vision, and three stated that they had a greater. One of these was the painter who located the images at the back of his head at a distance of three feet.

Thirteen of the artists said that they thought their command over their visual mental images is good. Two said their 
images do not move. One said that his images of people do not move because for years his only training (as that of all artists) has been to ' see them still.'

Nine said they recall familiar faces better and two said no better.

Those who recalled natural scenery in mental imagery were seventeen. (Nine not reported.)

Twelve of these mentally illustrate books as they read, and four say they do not mentally illustrate.

As would naturally be expected, color preferences are exceedingly diverse, and peculiar associations with colors are frequent. The order of preference for the twenty-seven artists under consideration now is, red, yellow, blue, brown and purple, violet and gray, the last being least preferred.

Among the peculiar associations is that of dizziness with red. One artist said that he became dizzy if his whole field of vision was filled with red, mentioning a matador's cloak which hung in his studio.

Two have a curious attitude towards blue. One likes it, but finds it hard to manage. Another, who prefers reds, said of blue that he feels towards it as if it were on a different (higher) social plane than his own.

Another described his attitude towards certain colors thus : Yellow is salt to him, accountable possibly on the score of salt butter. Green is acid, purplish greens being worse; they are bitter, acrid. Red is peppery. Blue stands for shadow and emptiness. Yellow is his favorite color, but that is indefinite, for his liking for colors depends entirely upon the nuance.

Of the eight only who gave definite answers to the question (I0) "Is your mental imagery now fainter than in childhood?" five said it was and three said it was not fainter but better. As proof of this, one or two cited examples of quasi hallucinations seen in childhood, imageries which were much more vivid than theirs of the present day, but the others, generally, said they had noticed a gradual fading of their mental imagery.

One of those who said his mental imagery is better now than ever, paints largely from memory and visualizes numbers and the chess board. 
Of the eight who replied to the question " Do you paint from memory?" only one gave a negative answer.

Of the seventeen who answered the question, "Do you seem to hear any voice in your mind's ear when reading to yourself? " seven replied in the affirmative and ten in the negative. Of the former one, a sculptor, seems to hear his own voice raised when he reads italics. ${ }^{1}$

Of the foregoing seventeen, five dispense with mental words in doing sums in arithmetic, eight do not and four are doubtful.

Of the seventeen whose thinking in words was questioned eight seemed to articulate and five seemed to hear the words. One seems to hear the words only. The others found it impossible to analyze.

Eight could think the word bubble when the mouth is open and two could not. One of the latter seemed to articulate when he read to himself and neither seemed to hear when reading to himself.

The appearance of the apple was brought before the minds of all who answered the question concerning the apple's taste or appearance.

In recalling sensations of touch, taste and smell, all who were questioned, except five, lacked the memory of at least one of these, some two.

Among the twenty-seven artists orally questioned I found only two with number forms. One other had a form for the week.

\section{Experiment $C$.}

Another method of studying the mental imagery of other people is the examination of works of the imagination. All works of the imagination must give scope for the mental imagery. In poetry in particular we see a wide field for the study of imagery of various kinds. We can infer from the carefully polished lines of Tennyson that he had a good auditory mental imagery and also from the references to sound which occur in the poems, we may see that little that is beautiful in pure sound escaped him, and that the auditory mental-imagery was a potent factor in the creation of his poems.

${ }^{1}$ One, who thinks he mentally articulates, says that, after reading to himself a few pages of Browning, his jaws become tired. 
And it may be seen also in other poets that various sensuous elements were dominant in their minds. Swinburne seems to revel in the sound of the wind, and his verses are full of the 'windy suspirations of forced breath' in the letters of the alphabet most numerous in the words he uses. In Atalanta in Calydon sibilants and fricatives are used more than any other class of consonant. If he can, he uses a word with $f, v, s$, or sh in it, as if to give it an atmosphere of blowing winds.

Browning strengthens and roughens the sound of his verse by the use of a great number of gutturals and dentals.

Consonants in Browning, Shelley, Tennyson, etc.

I counted the consonants in eight pieces of literature, five of which were parts of poems and one a part of a play (Othello), the other two being a passage from Burke and a passage from Green. I used the consonant scheme found in Sweet's Handbook of Phonetics. The results are as follows, arranged first in groups of similar consonants :

TABLE II.

\begin{tabular}{|c|c|c|c|c|c|c|c|c|}
\hline \multirow[t]{3}{*}{ Author. } & \multicolumn{8}{|c|}{ Consonants. } \\
\hline & \multirow{2}{*}{ 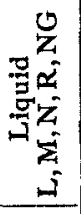 } & \multicolumn{3}{|c|}{ Mutes. } & \multirow{2}{*}{ 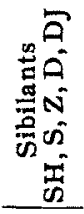 } & \multirow{2}{*}{ 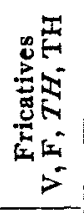 } & \multirow{2}{*}{ 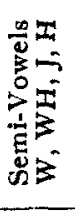 } & \multirow[b]{2}{*}{$\dot{2}$} \\
\hline & & $\begin{array}{l}D \\
B\end{array}$ & 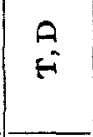 & $\begin{array}{l}0 \\
0\end{array}$ & & & & \\
\hline Green, ...... & $34 \cdot 35$ & $6 . \infty$ & $\mathbf{1 5} .95$ & 6.05 & 14.65 & 14.75 & 6.80 & 2000 \\
\hline Burke, . . . . . & $37 \cdot 3^{2}$ & 6.56 & 18.34 & 5.20 & 15.92 & 13.12 & $5 \cdot 46$ & 5000 \\
\hline Tennyson, . . . . & $3^{8.60}$ & 5.10 & 17.80 & 4.45 & กा. 87 & 13.70 & 7.60 & 2000 \\
\hline Browning, . . . . & 33.10 & 6.85 & 16.50 & 5.85 & 17.05 & 12.05 & 7.25 & 2000 \\
\hline Swinburne, . . . & 37.25 & 4. 10 & 16.90 & 3.10 & 14.15 & 16.90 & 6.85 & 2000 \\
\hline $\left.\begin{array}{c}\text { Shakespeare, } \\
\text { (Venus and Adonis), }\end{array}\right\}$ & 34.05 & 6.35 & 17.80 & $5 \cdot 45$ & 15.60 & 11.25 & 8.80 & 2000 \\
\hline Shakespeare (Othello), & 34.22 & $5 \cdot 74$ & 15.28 & 4.94 & $15 \cdot 30$ & 12.34 & 8.98 & 5000 \\
\hline Shelley, . . . & 37.06 & $5 \cdot 10$ & 17.68 & $4 \cdot 5^{2}$ & I4.10 & $12.3^{\circ}$ & 7.84 & $\begin{array}{r}5000 \\
25000\end{array}$ \\
\hline
\end{tabular}


TABLE III.

Per Cent. of Each Consonant in the Eight Examples.

\begin{tabular}{|c|c|c|c|c|c|c|c|c|}
\hline Letters. & Burke. ${ }^{1}$ & $\begin{array}{c}\text { Ten- } \\
\text { nyson.2 }\end{array}$ & $\begin{array}{c}\text { Swin- } \\
\text { burne. }\end{array}$ & $\begin{array}{l}\text { Venus } \\
\text { and } \\
\text { Adonis.t }\end{array}$ & Othello. & Shelley." & Green. ${ }^{7}$ & $\begin{array}{l}\text { Brown- } \\
\text { ing. }^{8}\end{array}$ \\
\hline $\begin{array}{l}\text { SH } \\
\text { P } \\
\text { W } \\
H \\
\text { F } \\
\text { M } \\
\text { D } \\
\text { S } \\
\text { T } \\
\text { R } \\
\text { N } \\
\text { L } \\
\text { TH } \\
Z \\
\text { K } \\
\text { B } \\
\text { V } \\
\text { NG } \\
\text { G } \\
\text { J }^{11} \\
\text { TH } \\
\text { TS } \\
\text { DJ' } \\
\text { WH }^{13} \\
\text { ZH }^{14}\end{array}$ & $\begin{array}{l}2 .+ \\
3 .+ \\
1.8+ \\
1.6+ \\
3 . \\
4 .+ \\
8 . \\
6.9 \\
10 .+ \\
12 .+ \\
12 .+ \\
6 . \\
5.7+ \\
5.7+ \\
3.9 \\
3 .++ \\
3.8 \\
1.7+ \\
1.2+ \\
.9+ \\
.5 \\
1.3+ \\
.8+ \\
1 .+1 \\
.1\end{array}$ & $\begin{array}{l}.9+ \\
2 .+ \\
2 .+ \\
3.7+ \\
3 . \\
5 . \\
7 .+ \\
6.12 \\
10 . \\
12 .+ \\
11 .+ \\
8 . \\
6 .+ \\
4 .+ \\
3 .+ \\
2 .+ \\
2 .+ \\
1 .+ \\
1 .+ \\
.8 \\
1.2 \\
.8 \\
.7 \\
.5 \\
.05\end{array}$ & $\begin{array}{l}1.3+ \\
1.6+ \\
3 .+ \\
2 .+ \\
5 .+ \\
3 . \\
8 . \\
6 . \\
8 . \\
11 . \\
12 .+ \\
7 .+ \\
7 .+ \\
6 . \\
2 . \\
2 . \\
3 .+ \\
2 .+ \\
1 . \\
.4 \\
.45 \\
.4 \\
.3 \\
.15 \\
0 .\end{array}$ & $\begin{array}{l}2 .+ \\
2 .+ \\
2 .+ \\
4 .+ \\
3.1 \\
3 .+ \\
7 .+ \\
7 .+ \\
9 .+ \\
11 . \\
10 . \\
6 . \\
4 . \\
5 . \\
3 .+ \\
3 .+ \\
2 .+ \\
2 . \\
1 .+ \\
.25 \\
1 . \\
1 . \\
.4 \\
.7+ \\
0 .\end{array}$ & $\begin{array}{l}1 . \\
2 .+ \\
2 . \\
3 .+ \\
3 . \\
5 .+ \\
6 .+ \\
8 . \\
8 .+ \\
11 .+ \\
10 .+ \\
5 . \\
5 . \\
5 . \\
3 .+ \\
2 .+ \\
3 . \\
.9 \\
1 . \\
2 . \\
.8+ \\
1.0 \\
.8 \\
1 . \\
.06\end{array}$ & $\begin{array}{l}\text { I. } \\
3 . \\
3 . \\
3 . \\
3 . \\
5 . \\
8 .+ \\
7 .+ \\
9 . \\
11 .+ \\
11 . \\
7 . \\
5 . \\
5 . \\
3 .+ \\
2 . \\
2 .+ \\
1 .+ \\
1 . \\
.7 \\
1 . \\
.8 \\
.3+ \\
.9 \\
.06\end{array}$ & $\begin{array}{l}1 .+ \\
2 .+ \\
2 . \\
3 . \\
3 . \\
3 .+ \\
7 .+ \\
7 .+ \\
8 . \\
11 .+ \\
11 .+ \\
6 . \\
5 .+ \\
3 .+ \\
4 . \\
3 . \\
4 . \\
1 . \\
1 .+ \\
.8+ \\
1 .+ \\
.9 \\
1 . \\
.5 \\
.25\end{array}$ & $\begin{array}{l}1 . \\
4 . \\
2 . \\
2 .+ \\
3 . \\
4 . \\
6 . \\
10 . \\
10 . \\
9 .+ \\
10 . \\
7 .+ \\
5 . \\
4 . \\
4 . \\
2 .+ \\
3 . \\
1 . \\
1 . \\
1 . \\
1 . \\
1 .+ \\
1 . \\
1 . \\
.1\end{array}$ \\
\hline
\end{tabular}

'The 5,000 consonants from Burke's Revolution in France, Vol. 2, pp. 87-94 in the Clarendon Press edition of his works.

2The 2,000 consonants in the first 117 lines of Tennyson's Enid.

3 The 2,000 consonants in the first i I lines of Swinburne's Atalanta in Calydon.

1The 2,000 consonants in the first 115 lines of Shakespeare's Venus and Adonis.

${ }^{6}$ The 5,000 consonants from the opening of Othello.

- The 5,000 consonants in the first 186 lines of Shelley's Adonais.

'From Green's Short History of the English People.

${ }^{8}$ The 2,000 consonants of the first 117 lines of Browning's The Ring and the Book.

${ }^{\mathbf{9}} \mathbf{T H}=$ th in ' than.'

${ }^{10} \mathrm{NG}=\mathrm{ng}$ in 'sing.'

$11 \mathrm{~J}=\mathrm{y}$ in 'yes.'

${ }^{12} \mathrm{TH}=$ th in 'thing.'

${ }^{3} \mathrm{DJ}=\mathrm{j}$ in ' just.'

1s $\mathbf{Z H}=\mathrm{s}$ in 'pleasure.' 
In the preceding tables it will be noticed that Swinburne's use of the fricatives in Atalanta and Calydon is very great, being nearly five per cent. greater than Browning's, and that Browning has a large percentage of sibilants. The liquids are most numerous in Tennyson, Burke, Swinburne and Shelley, and least numerous in Browning.

The two excerpts from Shakespeare show a general likeness that is remarkable, there being a great difference only in the mutes $T$ and $D$. His liquids are remarkably few and the other consonants do not differ much from the average except in the case of the sibilants and semi-vowels, which are greatly in excess of those of the other poets examined. It is hardly fair, however, to judge Shakespeare by modern pronunciation.

Tennyson, shows besides a preponderance of liquids, a large number of lingual mutes, the others being below the average, the smallest number recorded of sibilants, about the average of fricatives and a little more than the average of semi-vowels.

Browning has, compared with the average, few liquids, few lingual mutes, many labial and palatal mutes, very many sibilants, few fricatives and few semi-vowels.

Swinburne has many liquids, very few mutes, few sibilants, very many fricatives and few semi-vowels. (Burke, alone, has fewer semi-vowels.)

Shelley has very many liquids, few mutes, except linguals, few sibilants, few fricatives and many semi-vowels.

The table on the following page shows the relative frequency of each consonant.

It must be that the poet whose rough consonants are greatly in excess of the average has either a less sensitive 'ear' than the one whose liquids are the most numerous, or uses them as an expression of strength. Now, an ' ear' in the sense above used means the possession of mental imagery of the auditory kind and we may then say that Tennyson and Shelley had a better ear than Browning. ${ }^{1}$ That Shelley's liquid $\mathrm{N}$ is so far in

1 'Ear' does not mean here, however, a capacity for understanding and appreciating good music, for it is well known that Tennyson and Swinburne have no ear in this sense and that, curiously enough, Browning had. He was, as an amateur, a thorough musician. 


\begin{tabular}{|c|c|c|c|c|c|c|c|c|c|}
\hline 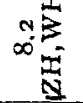 & & & 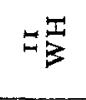 & $\sim$ & & $\operatorname{in} \bar{A}$ & $\infty \frac{I}{N}$ & $\nabla \frac{T}{N}$ & \\
\hline 富 & N & ヘロ & $\vec{A}$ & tr & $-\frac{T}{N}$ & $\Xi ロ$ & $\sigma \bar{\Omega}$ & $\sigma_{E}^{\mathbb{E}}$ & $-\stackrel{\mathbb{N}}{\mathbf{N}}$ \\
\hline$\tilde{\nabla}$ & $\stackrel{\sim}{H}$ & $\omega$ & 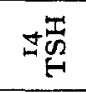 & $\sigma^{\circ}$ & 垴 & オむ & $\Xi-$ & 部 & 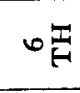 \\
\hline$\Xi m$ & 9 & $\stackrel{4}{T}$ & 果 & $\stackrel{T}{\mathscr{T}}$ & $+\frac{\pi}{\sigma 0}$ & 电 & $\approx$ & 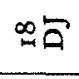 & $ت m$ \\
\hline$\approx \pi$ & 总営 & $\sigma F$ & $\stackrel{\infty}{\infty}$ & $\sigma F$ & $\stackrel{F}{F}$ & $\stackrel{5}{*}$ & $\begin{array}{r}T \\
\frac{1}{2}\end{array}$ & 83 & $B$ \\
\hline$\stackrel{2}{2}$ & สร & $\underset{H}{\pi}$ & 90 & O & ד] & $\overrightarrow{N Q}$ & טָ & 䠱 & 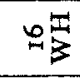 \\
\hline b & నర్ & ה & $8 \frac{\pi}{\Omega}$ & 梞 & W & $\sqrt{2} \equiv$ & $A \stackrel{T}{\pi}$ & तט & 90 \\
\hline$\sigma_{4}^{5}$ & טU & बुे & 跑 & के & ${ }^{2}$ & $\begin{array}{l}0 \\
\text { N }\end{array}$ & 空 & నర & ন্ত \\
\hline$\infty_{\infty}^{\infty}$ & 焉 & Fa & $g 3$ & Dex & F草 & $\exists \infty$ & $m_{z}^{u}$ & 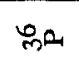 & $A B$ \\
\hline$y$ & s3 & $\vec{y}$ & on & $\stackrel{m}{\forall}$ & 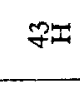 & q & $\stackrel{s p}{ }$ & 踪 & 品密 \\
\hline grp & $\forall \oplus$ & int & $\sin$ & $\pm m$ & $g>$ & in & $q_{n}$ & $\stackrel{\infty}{\forall}$ & J盾 \\
\hline$F_{\infty}$ & $\frac{9}{8}$ & int & in> & inst & $\begin{array}{l}i n \\
i n x\end{array}$ & 83 & ga & $g m$ & 30 \\
\hline 是里 & 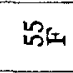 & 올 & sis & 올 & $B a$ & $\tilde{~} \tilde{x}$ & 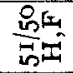 & 5.4 & 藏 \\
\hline intu & 80 & Jึ & $5 \pm$ & 83 & ธี & 82 & $6 x$ & 5 & $\ddot{B>}$ \\
\hline $\mathscr{8}: \mathbf{I}$ & $8 \Sigma$ & $8 x$ & $8 \pi$ & $8>$ & 81 & $5 \times 4$ & 83 & $8 \mathrm{~N}$ & 咄 \\
\hline IN & $\mathrm{RN}$ & $\nabla_{H}^{T}$ & $\infty N$ & न人ष & 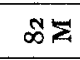 & $\infty 2$ & 8 & $8 z$ & 84 \\
\hline 85 & SN & $8 \pi$ & $\therefore+$ & $\Xi \approx$ & zूN & $8 N$ & $\Xi N$ & 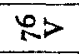 & $N \Sigma$ \\
\hline Sos & $\infty \pi$ & $8 N$ & $\infty_{H}^{I}$ & $\Xi N$ & 要 & $\delta_{F}^{I}$ & $J_{y} \bar{z}$ & $\infty_{H}^{I}$ & $\infty$ \\
\hline$\nabla_{F}^{T}$ & \$a & \&્ & $8 \pi$ & 胥I & 뽁 & $\mathbb{Z} \Omega$ & ब्ञิ山 & 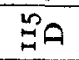 & $\Phi N$ \\
\hline$i n$ & 行 & लिA & \& $n$ & 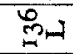 & $\stackrel{120}{6}$ & $\bar{\rho}-1$ & $\underset{7}{O} \Omega$ & EH & $5 \theta$ \\
\hline$\widehat{s i n}$ & $B$ & 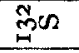 & 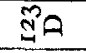 & ist & SิA & $\exists a$ & $\stackrel{B}{B}$ & $w_{-\infty}^{\infty}$ & $\tilde{m}^{\infty}$ \\
\hline $\mathbb{N}_{-1}^{N}$ & 5 & $\mathscr{b}_{H}$ & $\infty$ & 跑 & $\underset{B}{*}$ & $8 H$ & $\stackrel{\circ 0}{\circ}$ & 8 & $\ln _{n \rightarrow x}$ \\
\hline $8 z$ & 수쇼 & 尽z & $\stackrel{8}{\circ}$ & 8 & 8 & $\nsubseteq \mathrm{z}$ & $\underset{N}{2} \alpha$ & $\tilde{d}^{2} z$ & 8 \\
\hline$\frac{\pi}{N} x$ & $\frac{9}{7} z$ & $\$ \pi$ & $\mathcal{B u}_{H}$ & ल) & $\sqrt[2 n]{z}$ & $\bar{\pi} \pi$ & స్ల & ${ }^{2} \mathrm{O} F$ & d \\
\hline 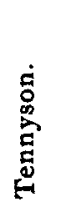 & 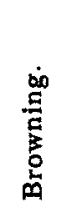 & 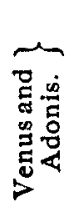 & 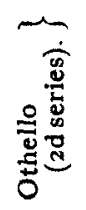 & 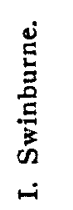 & 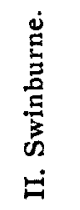 & $\frac{\dot{\sigma}}{\stackrel{\vec{\varpi}}{\sigma}}$ & 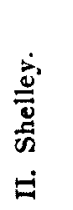 & $\begin{array}{l}\dot{\dot{d}} \\
\stackrel{\dot{\Xi}}{\dot{m}} \\
\dot{\leftrightarrow}\end{array}$ & $\begin{array}{l}\dot{\dot{s}} \\
\text { 音 } \\
\dot{\omega}\end{array}$ \\
\hline
\end{tabular}


advance of all the others except the same letter in Swinburne argues a conscious preference for that letter. And this is not affected by the fact that in all cases except Othello the letters $\mathrm{R}$ or $\mathrm{N}$ heads the list.

Tennyson (with several others, such as Rossetti) seems to have paid particular attention to the mental imagery of the five senses, that his poems would excite. His appeals to the visual imagery are often pictures with a studied effect qua pictures, ${ }^{1}$ and while we listen to his voice we see more than we hear. $\mathrm{He}$ is most careful to change the pictures not too rapidly and to present them in such an order that they shall have the best effect upon the mind's eye. There is, occasionally, in one of his lines nothing more than a single visual, pictorial aspect of what he describes, $e$. $g$., from the Princess :

"And I sat down and wrote, As when a field of corn bows all its ears, Before the roaring east."

Such lines of Tennyson and some of Wordsworth and of Rossetti and others having nothing but a purely visual content, are to be contrasted with many lines of other poets, which contain only the sound of the words and possibly a slight emotional or organic imagery. If we attempt to visualize such lines as

\footnotetext{
"To take up arms against a sea of troubles And by opposing, end them."
}

the result is often the purest visual nonsense. These lines have indeed made great trouble for the commentators.

\section{Experiment $D$.}

I have examined, also, the first I, ooo lines of Tennyson's The Marriage of Geraint, and the first I, ooo lines of Browning's The Ring and the Book, marking in each the various imagery that are awakened by reading the lines. In doing so I can only take myself as an example of the average reader. senses).

1 Cf. Oenone, lines $90-100$ (the poem contains appeals to all the five 
Here are the results :

\begin{tabular}{|c|c|c|}
\hline $\begin{array}{c}\text { In the first } x, \infty 00 \text { lines of } \\
\text { There are }\end{array}$ & $\begin{array}{l}\text { TrNNyson. } \\
\text { Examples. }\end{array}$ & $\begin{array}{l}\text { BRownING. } \\
\text { Examples. }\end{array}$ \\
\hline Visual imagery, . . . . . & . $\quad 8_{3}$ & 107 \\
\hline Auditory imagery, . . . . & 48 & 40 \\
\hline Olfactory imagery, . . . & $\circ$ & 2 \\
\hline Motor imagery, . . . . . . & $\mathbf{I}$ & ro \\
\hline Thermal imagery, . . . . & $\mathbf{I}$ & 3 \\
\hline Tactile imagery, . . . . . & 7 & II \\
\hline Organic imagery, . . . & 3 & 4 \\
\hline Gustatory imagery, . . . . & 0 & 4 \\
\hline
\end{tabular}

Examples of the various imageries as they appealed to my mental sensations are :

VISUAL.

\section{TenNyson.}

But never light and shade Coursed one another more on open ground.

Beneath a troubled heaven than red and pale

Across the face of Enid.

1. 521 .
Browning.

I saw the star supposed, but fog o' the fen,

Gilded star fashion by a glint from hell.

1. 544 .

\section{AUDITORY.}

Each of whom had broken on him Once let smoke rise untroubled, we A lance that splintered like an icicle. decry

1. 938. Clearlier what tongues of fame may spire and spit

To eye and ear.

1. 935 .

\section{OLFACTORY.}

Who, breathing musk from lace work and brocade.

1. 919 .

\section{MOTOR.}

At this he hurled his huge limbs out of Do you see this square old yellow book

bed,

And shook his drowsy squire awake.

\section{I toss}

I' the air and catch again and twirl about?

1. 33 .

THERMAL.

Made her cheek burn and either eyelid fall.
1. 775 .
[I] stepped out on the narrow terrace built

Over the street and opposite the church,

And paced its lozenge brick work sprinkled cool.
1. 478 . 
TACTILE.

Whom first she kissed on either cheek, and then

On either shining shoulder laid a kand.
1. $5 \mathrm{I} 7$.
And since the course was much to his own mind

Of pinching flesh and pulling bone from bone,

To unhusk truth a-hiding in its hulls.

1. 977 .

ORGANIC.

She found no rest and ever failed to draw

The not unpleasant futter at the breast.

I. 860 .

The quiet night into her blood.

1. $53 \mathrm{I}$.

GUSTATORY.

Taste come vituperation, bite away.

Whether at marjoram sprig or garlic clove.

1. $3 \times 3$.

The auditory imageries are, however, made up largely of ' conversation,' for which I seem to fancy the voice of the speaker.

All these are, however, but objective methods wherein the result is accurate only to the third or fourth remove, because of misunderstanding of questions, of wilful perversion of answers and of the great difficulty of collation and comparison, as well as of the danger of reading my own mental imagery into the words of the others.

The only way, then, in which the phenomena of mental imagery can be studied at first hand and brought to a quantitative result is by my examination of my own mental imagery.

I began to study my own mental imagery in I894, while reading a work on philosophy, which, I soon observed, did not wholly take up my attention. I was not in very good physical health and my mind wandered extensively. I soon appreciated that there was more interest in watching the inconsequences of my mind, which were exhibited in a rapid sequence of sense images, than in trying to 'make sense out of' the abstract language of the philosophy book. So I made a record of the times when my mind wandering or, as I should call it, my secondary thought-current entirely superseded, to its complete obliteration, that aroused by the words of the book. This 
secondary thought-current may have resulted from my vain attempts to read sense imagery into the abstract language of the book I had been reading-a sort of reaction.

My attention having been fixed upon the secondary current (secondary only in being apart from my appointed work; it was primary in intensity) I proceeded to make records of it. I found that even though I approached the sense imagery consciously, it seemed to pass as regularly as, and more freely than, before. I tried it one or two nights before going to bed, and in the afternoons after some hours of philosophical reading.

After several experiments I devised the following

\section{Method of Observing and Recording My Own Mental IMAGERY.}

\section{Experiment $E$.}

I take a piece of paper with fifty spaces marked on it, and sitting at my desk in as quiet a time as possible, I write down in each space a word or words descriptive of the mental imagery which goes on before my mental eye, ear, etc., hurrying from one word to another until the fifty spaces have been filled. Then I take the time elapsed and as quickly and as carefully as may be I look over the words and record whether what they stand for is visual or any other mental imagery. This, after some practice, is comparatively easy.

I appreciate the crudeness of this method, but I was unable to devise a better, for words seem to be the only way of recording mental imagery.

When performing this experiment the mental imageries change with the greatest rapidity and almost maniacal incoherence, and I confess that only a portion of the mental images are transferred into words. Some of them cannot be on account of the poverty of the language and others are not to be expressed in single words or short phrases. On the other hand, to write out afterwards a complete description of the mental imagery which I had already recorded during one five minutes, would be impossible, for, in the time taken to describe that current, new 
mental imageries would arise which did not really belong to it, and it would be impossible exactly to discriminate between what mental imagery occurred from I I.00-II.05 a. m., for instance, and that recurring in the remainder of a half hour.

The words, of course, dragged in a good many pictures, sounds, smells, etc., which would not have occurred to me if I had not tried to record my train of thought, nevertheless the result was a number of mental images of various kinds which, $I$ believe, showed the tendency, at any rate the possibilities of my mind at that particular time. And, after recording many sights, a few sounds, etc., even if I did think to myself, "Suppose you have a few smells, tastes and touches occur to you," I believe, even so, that shows, as well as anything else, the quality of the mental imagery that I may have.

It seems again to be a matter of total indifference whether the lists be made out in entire isolation or not. If I do see or hear distracting things while writing the list, all that is necessary is to put down words descriptive not of the sensation, but of the mental images. If the 'thought stream' be all sensation and no mental images, then wait until mental imagery begins again and observe that alone.

Here is a sample of the blanks as I fill them out myself :

12/30/97//1 1.08 A M $41 / 4$ min. 5 balks $^{1}$

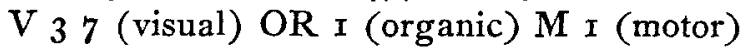

W 9 (words only) OL I (olfactory) A I (auditory).

$\mathrm{V}$ F

$\mathrm{V} \mathrm{C}-$

$\mathrm{V}$ bookstore

$\mathrm{V} \mathrm{M}-$

W Lester

W Kester

A N-

V Mr. M-

$\mathrm{V}$ castle

$\mathrm{V} \mathrm{A}-\mathrm{B}$

$\checkmark$ El. Road

V Mazetti's

$V$ Duquenne's

$\mathrm{V}$ tables

$V$ her home

$\mathrm{V}$ her garden

$\mathrm{W}$ self reading paper

$\mathrm{V}$ psy. lecture room

O smell

$\mathrm{V}$ C-

$\mathrm{W}$ words

V Mc. W

'By balks I mean the absolute blank which is the state of $\mathrm{my}$ mind when neither words nor images come. This will be noticed below. 
W of D's restaurant

$\mathrm{V}$ steam

$\mathrm{W}$ visual

$\mathrm{V}$ deliv. wagon

$V$ real est. ag.

V W-

$\mathrm{V}$ 6th ave

$\mathrm{V}$ palmist's sign

W Paderewski

M holds self to seat

$\mathrm{V}$ Mac D-

$\mathrm{V}$ college buildings

$\mathrm{V}$ clean

$\mathrm{V}$ fresh
$\mathrm{V}$ exercises

$V$ his desk

$\mathrm{V}$ window

$\mathrm{V}$ seminar

$\mathrm{V}$ room

V blackboard

V Mr. T

$\mathrm{W}$ cats and kittens

$\mathrm{V}$ pictures of boxes

$\mathrm{V}$ woman student

ORG gone feeling

$\mathrm{W}$ bad taste

$\mathrm{V}$ ground glass

$\mathrm{V}$ wood work

Here follow the results of 2,500 recorded mental images collated during two years, $1896-8$ :

$\begin{array}{lc}\text { Mental Images. } & \text { Per Cent } \\ \text { Visual. } & 57 \cdot 4 \\ \text { Auditory. } & 28.76 \\ \text { Olfactory. } & 5.88 \\ \text { Gustatory. } & .5^{8} \\ \text { Temperature. } & 2.0 \\ \text { Touch. } & 3.84 \\ \text { Organic. } & 1.1 \\ \text { Motor. } & .32 \\ \text { Emotional. } & .12 \\ & -100 .\end{array}$

Average time for each group of 50 experiments, minutes, $\quad 7.39$

Average number of balks for each group of 50 experiments, 1.46

In some cases my mental imagery has run largely in terms of a single sense. It must be confessed that in such cases, where the thought stream is made up almost entirely of sensations (like smells) usually in the minority, there is generally a synchronous visual current. For instance, in one of the experiments where the imagery reported was largely olfactory, while I had the salt smell of the ocean in my ' mind's nose,' as it were, I quite distinctly visualized a bit of ocean seen from the deck of a steamer out of sight of land, and had a feeling of north of

${ }^{1}$ Including words without other imagery. Words accompanied by other imagery are ignored for the sake of the imagery. 
Cape Cod and east of Gloucester and of looking in a northeasterly direction.

While mentally smelling 'dead fish' I seemed also to see two figures standing on the shore of Great South Bay looking at something in the sand. (It was a dead balloon fish but at 8.39 P. M. several months later, I did not see that fish in my mental imagery.) There existed then only the smell and the vision just described. I seemed to be at a distance of about 200 feet from the figures in a lane leading to the beach. 'Drift wood' I seemed to see also-a piece half hidden by the sand (but this was in Connecticut) and worn smooth by the water and sand in which it had been rolling.

' Wet sail'-here the scene shifts again to the Great South Bay and I seem to be unfurling or furling a sail on a cat-boat headed S. W. towards Fire Island inlet. Here some of the thought content is visual and some a feeling of direction.

Lavender-this was accompanied by a visual mental image of glass smelling-bottle on a dressing table.

$E m$.- this is the 'feeling of absence' with the smell not increased, but, I feel quite certain, a dim hazy lavender color before my mind's eye. It may have got the word from the color. I am not sure.

With Brass I recall no image save the smell of dirty brass.

Same of Kerosene.

Association seems to have worked so fast by words that I got 'tobacco' without any smell. (I hadn't smoked for nearly a month.)

'Steel'-here I felt the touch also of the back of my razor against my noze, both smooth (Touch) and cold (Temperature).

With 'old books' I saw the dusty-speckled edge of a papercovered edition of some novel.

With 'sugar candy' I had an odor of wintergreen or cinnamon, and the words 'sugar candy' and the appearance of the shiny little satin pillows they call 'buttercups,' which I now appreciate, are not sugar candy at all.

The 'violcts' existed for me more as something cool and dewy touching my nose.

With 'hoof burning' I seemed to see a cloud of smoke 
curling out of the open door of a blacksmith's shop where the red-hot shoe was being put on.

With 'aroma' I seemed to have a dark brown earth color come before my mind's eye.

This is as free from subsequent interpolation as I can make it.

Examples of the Various Types of Mental Imagery Observed in Myself.

I give some examples of each specific manifestation of it as it has come to me in the experiments.

I. Visual mental imagery is familiar to every one, ${ }^{1}$ and I think all have observed the infinite gradations between the faintest visual imagery and the strongest, the former approaching mere mental blank and the latter almost an hallucination.

A good illustration would be the rising (or the crescent) moon or the falling snow. Any of these is pure visualization. Others are too obvious to require mention.

2. Auditory Mental Imagery. I find the auditory mental imagery in my case to be almost as important a factor in my mental life as is the visual, being a mental reproduction of the sounds I have heard-musical or otherwise. They are comparable with real sounds not so much in intensity, but perfectly with timbre, pitch and duration. I can estimate a minute with much greater exactness mentally if $I$ listen to the auditory mental imagery of a piece of music which takes about a minute to perform.

The auditory mental imagery, I would say, includes all the actual word thinking that $I$ do, which is almost always done by means of writing.

See page 42 for analysis of word imagery.

3. The Tactile Mental Imagery. This seems to me as clear and strong as any other, occasionally stronger. The imagination of touches gives me real pain, such as the image of touching velvet with the part of the finger which is uncovered

${ }^{1}$ So visual are we that our very language testifies to it. Among the many instances could be cited that art commonly, unless otherwise specified, means pictorial art. 
by cutting the nails short. Also it is a really painful thing to think of a finger nail cut or torn to the quick. But the feeling of various things touching all parts of my body, from the feeling of various foods in the mouth (which influences my liking or dislike for certain of them) to the feeling of the water on the skin as one dives into the ocean, there are innumerable things which give in imagination, in mental imagery, almost the same pleasure or pain, as the real sensations gave in the past or will give in the future.

4. Gustatory Mental Imagery. In my lists of 2,500 mental images I have registered only twelve instances of the arising of gustatory imagery, and of these only four could be said to be true gustatories, viz.: The tart taste of an apple, the salt taste of sea water, the sweet taste of broiled lobster, the bitter taste of ale.

Sour and bitter are the only tastes I revive quite clearly, the others being three parts visualization and olfactory. I have mental imagery of things that are sweet, such as vanilla wafers, but it is the flavor and the touch (on the tongue) and not the taste which is uppermost.

5. Olfactory Mental Imagery. These are in my own case extremely numerous, probably because to me so many things have a smell, often a distinctive smell. One recalls at once in this connection the very potent and sometimes mysterious, associative qualities these sensations have. We are often set to thinking of other times by the recurrence of an odor long unsmelled, and sometimes are at a loss to understand how we should have been thinking of this thing so suddenly. These mental images have to me, like those of the other senses, quite distinctive qualities. The mental image of the smell of new-mown hay is totally unlike, even as a purely mental occurrence, that of the aroma of forest leaf mold. And the words ' tea' and 'coffee' are represented in my mind by two mental images, totally unlike.

The person who traced an association by the subsequently smelled fragrance of a flower had no mental imagery of the smell. I, on the contrary, have had many different olfactory images in a room full of tobacco smoke. The tobacco smoke, 
however, as one and the same sensation, soon becomes nothing, qua odor, and the mind is thus left free to think of others. In quickly changing odors it is harder to imagine smells foreign to the current sensation than to perceive the last.

6. Thermal Mental Imagery, or the mental imagery of heat. This is a feeling so slight in intensity that it is hardly perceptible and is, in one instance, a feeling of heat about the head, the feeling of a red face. One can also imagine a hot body approach the face and feel the heat mentally. The percentage of my own thermal mental imagery is only $2 \%$ and contains such imageries as 'warm feet,' ' cold nose,' etc. Out of forty-five examples seventeen were 'warm' and twenty-eight were 'cold.'

7. Motor Mental Imagery. This is the name which I should give to the mental imagery which has sometimes possession of us when we are imagining ourselves to be running or swimming, or, in fact, moving any part of the body. ${ }^{1}$ These, also, form a very small proportion of the mental imageries which I have noted down at the times when I recorded them. These included the imagery of running down a hill and walking. They are so largely contained in visual or other imagery as to be very faint qua motor mental images.

8. Mental Imagery of Pain. In my regular observation and recording of mental imagery I have not found a single instance of this which, however far removed from the etymological sense of the word imagery, I can yet affirm to exist in me. I can imagine pain, e.g., that of a stubbed toe, a cut, or a pounded finger.

9. Organic Mental Imagery. Among these are those of hunger, thirst, etc. These two have not occurred in the lists of mental imageries made during my experiments. But while one cannot "cloy the hungry edge of appetite with bare imagination of a feast," it seems that the imagery of physical plenitude is more likely to occur than the imagery of hunger.

ro. Mental Imagery of Emotions. This is a kind of mental imagery which, though very difficult to distinguish from the thing of which it is the copy, seems nevertheless to be a verit-

${ }^{1}$ It probably accounts for the phenomenon of the phantom hand in people who have lost an arm. 
able mental state, something quite apart from, and an increment to, a combination of other mental imagery. The thrill which I feel when I think of anything particularly joyous or fortunate may be a mental image or a sensation. Possibly one thrill is a mental image and another is a sensation. Here at any rate is where the former and the latter shade off one into the other. One is here strongly tempted to include with mental imagery all the finer emotions which do not exhibit themselves outwardly by flushed (or pale) face, quaking limbs or trembling voice. But to do this would lead me too far and I shall have to content myself with the description of an emotion of which $I$ subsequently experienced the re-echo or the mental imagery.

On a Staten Island ferry boat going to St. George I sat on the forward saloon deck near one of those small summer orchestras of four or five pieces which are seen on all the Staten Island ferry boats. While they were playing one of the popular airs the steam whistle of the boat sounded a long blast covering ten or twelve bars of the tune they were performing. The experience was pleasureable while it lasted (probably less than half a minute). ${ }^{1}$ The first effect of the blast of the whistle was to remove the musicians apparently to a great distance, to rob their music (?) of all but its sawing and scraping and wheezing qualities, which became as soft as the 'voice of a gnat,' and to take all the color out of it. It was-as if I had been looking at a colored print and then put a red or purple glass before my eyes through which to look at it. The glass would, by making it all one color, take all the colors out of it and reduce it to a mere outline. And so with the harp and violins in question. The greater noise threw them into distance and made a dangling cobweb out of their butterfly wings. They lost their importance for my attention which was filled with the sound of the steam whistle. I believe they contributed, however, to its effect upon me.

1 There is something analogous to this in music, viz., what is known as a pedal or organ point where one note, usually the key note or its fifth, is held through several bars, while chords containing notes discordant to it are played. This gave a far more piquant sensation than any pedal I ever heard. I am unable to say whether, in tone, it happened to be a pedal to the music then being played. I believe not. 
Besides the trembling thrill about the diaphragm, caused by the vibrations of the low tone of the blast and by the rumbling of the paddle wheels, the irregular dashing of waves against the bow of the boat-all of which were present in my consciousness at the time-I seemed to feel an abandonment to motion (chiefly visual), a rising above the world, $i$. e., a feeling of superiority, of regarding things from a lofty and distant point of view, of the transitoriness and bizarre aspect of life; a feeling of reckless irresponsibility, a sense, at the same time, of progress, yet of tranquillity and of eternity-complete leisure and absence of worry in the midst of the most intense motion, swinging, swirling, sweeping, sliding, shooting-rest in motion-the sleep of a spinning top, the sleepiness of the hills on a summer afternoon, and the motion of the earth in space, all in one short moment while the whistle was blowing. When it stopped, I was returned to the world and its motley complex of intuition.

This feeling is produced somewhat by any rhythmical sounds overwhelmed in intensity by a uniform, even tone, or possibly any short sounds permeated by a long one or a long series of shorter ones, such as the roar of Broadway drowning the noise of a 'piano organ.'

Possibly this feeling might be better defined by saying that it is one which not only these few words but a whole volume would fail adequately to describe. It is a lifetime feeling which it takes all the other mental imageries to represent or all the sensations of a lifetime to equal. At the time when it originally occurred, it contained no words, of course. It was the feeling pure and simple with certain visual and possibly motor concomitant mental imagery. It was more than these words could now arouse in me.

The importance of this feeling here is the recurrence of it in the form of mental imagery two years after the real emotions occurred.

\section{WORD IMAGERY.}

In respect to the mental imagery of words or, as I shall call it, word imagery, people differ. ${ }^{1}$ I shall confine myself to the

\footnotetext{
1 The locus classicus being of course Stricker vs. his many French opponents.
} 
consideration of my own word imagery, reserving for some future time the comparison of different people from this point of view. Suffice it here to say, however, that I make only individual observation of my word imagery.

'Violin,' whatever it suggests to the mind, and it is probably different with different people, may exist in the mind for no matter how short a time entirely apart from the instrument whose appearance, tone, feeling in our hands, etc., it suggests. Is it a word in bluish ink on white paper, or in chalk upon a blackboard, or in script, old English or Roman type, or is it the tones of some one's voice, or the articulation upon our own lips? Possibly to a deaf mute it might be also the appearance of another's lips while speaking the word. In any case, whether visual, auditory or motor, it is different from itself in any other of these forms.

The mental imagery of words forms a most interesting and important subject for study. It seems probable that when once the attention is called to the different ways in which words exist in the mind, it will be possible for the psychologist to see better the different sensory aspects of the 'thought stream' and to study them more successfully than heretofore.

If language is not given man ' to conceal his thoughts with' it will be easily seen that language is deceptive from the fact that very many words are associated with the imageries of more than one sense, and misunderstanding is likely to result if, e.g., visualization is meant where aurilization or motilization is supplied by hearer or reader.

My attention was called, however, to the observation of even a narrower aspect of the existence of words in mental imagery by the slips of the pen and of the tongue which $I$ have observed in myself.

I have observed in my own case that the word is almost exclusively a heard word and from several examples of lapsus calami and linguce, particularly the former, I shall try to show that what I have observed at first hand in my own thought stream is witnessed to by objective facts of speech and handwriting.

Slips of the Tongue. When speaking, some persons, including myself, are conscious of what we are going to say just a 
short time before we say it. If, then, our word imagery (auditory or visual) gets too far ahead of our actual speech, sometimes there is a slip of the tongue. For instance, if we are saying ' no power whatever over,' etc., and the 'over' is heard while the 'what' is being uttered, we are, if we slip at all, more likely to say 'whatover' than 'whatever.' This is an actual lapsus lingua.'

Slips of the Pen. As I write I hear words in my own voice in my mind's ear and, as it were, I copy them down. When the voice goes too fast I am occasionally at the same time writing one word and hearing another. The mental imagery of the latter word not yet written is sometimes strong enough to overcome the resistance which is caused by actually writing the former word and to interpolate itself. Thus in writing the phrase 'Pliny's letters' I heard ' letters' when I had written ' $P l i$ ' and then started to write the word 'letters' so that before I could stop I had written Plil. This, to me, seems to be a clear case of auditory mental imagery overcoming the motor ordinarily used in writing.

I wrote 'principium individuationis' correctly yet aurilizing 'individuonis,' thus mentally omitting two syllables which were supplied (as three letters) by the hand alone. After I had written the word I thought "I have said to myself and must have written ' individuonis,' but found on looking back that all the letters were there. It is often the same with remember. I hear in my mind's ear 'remember' (three syllables, eight letters), but write ' rember' (six letters).

\section{ANalysis of my Word Imagery.}

Very often in thinking of something to say to anyone, the words formulate themselves in my mind, i.e., I hear them in my own mental voice; and then it is suggested to me either in the same voice or by a sort of mental shrinking from doing it: "No, you had better not say it now ;" or, " you had better wait a few minutes." Then my mental imagery changes in a flash. I

\footnotetext{
1 Others are 'dichomoty' (spoken) for 'dichotomy'; 'frankincelse' (melts) for frankincense; 'effecht' (on Fichte); 'interpretive' for 'interpretative :' 'denuce' for ' deduce.'
} 
am possibly in another part of the world and have different things before my mind's eye. The sentence of words previously mentioned, however, I do not know whether I have uttered. My memory of the previous mental image is itself a mental image, and is often as strong as the previous one, and it seems as if I may have said the words, but I am really in doubt. Then I ask some one to be sure.

As I think these words before writing them down, I hear them mentally in my own voice, so to speak. This mental voice is generally a little ahead of the words as they are being written, and when I regard it closely seems to constitute a wholly different thing from what might be called the fountain (or, perhaps, panorama) of my other, deeper thought. The voice goes on moving by grammatical clauses and phrases, and I have usually heard the clause by the time I have written the first two or three words of it. There it stops and allows me to catch up with it. As the words are heard by my mental ear, they are carefully compared with an indescribable feeling of rightness, or wrongness ; and they are tested for their capability of expressing the idea that I am trying to convey, which idea, again, is indescribable, being not words but a sort of emotional state. If they seem awkward or unfit, then other words do or do not immediately spring up of their own accord to replace the faulty word. If they do I try them one after another until I have the well-known feeling of satisfaction which is as well marked and sure as the jingle of a bell at the end of a line in typewriting. If they do not appear, I have to give up exactly that grammatical form of expressing the idea or I must resort to the dictionary to find a word that fits. In such a case my mind is for the moment an absolute blank. Verbally it is a blank, for no words will come, and unless I am describing some sight, sound or other sensation of which I retain the mental imagery before my mind's eye, it is altogether empty. If there was any mental imagery, that, of course, remains, and from that I pick up again the lost thread of my discourse.

All this time my pen watched by my external eye alone which for the time seems to act only as a censor of spelling has been scratching away and generally making mistakes. My auditory 
center is the seat of, or at any rate the immediate receptacle for, the verbal thought which I am about to write. This auditory center would then in turn seem to direct the hand-moving center or that part of it which governs the group of muscles which are used in writing. I believe that, immediately superintending this cheirographic center, must be a word-uttering or articulatory-motor centre which spells the words. This articulation is not however conscious, but would seem to be a little ahead of the actually appearing word and, as before stated, the audition is considerably ahead of that; thus :

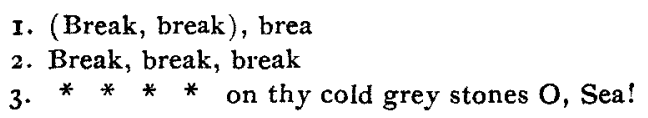

This scheme nearly represents the conditions at that period in writing Tennyson's verse when the pen has reached the third word. No. $I$ is the actual writing; 2 is that part of the articulatory process which seems to effect the spelling of the words, and 3 is the auditory form which the whole line has in my mind.

It is this word-articulatory imagery which seems to be the cause of some of the mistakes in writing, particularly those which would not be mistakes if the pronunciation were slightly altered. The substitution of a $b$ for a $p$ in the word 'pretty' is a mistake which is fundamentally phonetic. There is little in the shapes of the two letters that would lead them to be confounded by the hand as it writes them as would be the case were $I$ to write an $l$ for a $t$ or vice versa. In this latter case, which has never happened to me, there is a similarity in the shapes of the letters which might lead one to be written in place of the other, but there is no phonetic similarity. In like manner there seems to be no reason why so important a letter as $n$ 'graphologically' should be entirely ignored in writing a word as it has been by me in the logogram 'acient' which I wrote for 'ancient' and 'orage' which I wrote for 'orange.' Greater graphological dissimilarity with much phonetic similarity is shown by my writing 'answers' for 'ancestors' and in the mistake, common for me, of writing ' $n t s$ ' for ' nce' in such words as 'correspondents.' Also the logogram 'notwithistanding.' 
Capital letters, of course, have no phonetic existence, being purely a matter of looks. Accordingly, when I am writing very rapidly, all proper names are just as likely to come out with small initials, and more so, except in such cases of extremely well organized chirography as my signature; and my ordinary handwriting is covered with scratches made by my making such corrections, as I do just as soon as my eye comprehends that the word looks queer. Other mistakes of this nature are my writing ' to,' the word, for ' 2 ,' the figure; and such rampant phonetic spelling as ar for our and 'tranquil' spelt trank(uil).

In one case the spelt form of the word reacts on the sound of the word as I mentally hear it. Rough is written as two sounds, $r$ and $u f$, and there is no trace in that pot-hook $g$ of its guttural sound which it has when written from the auditory image of the sound of hard $g$. In writing the word Edinburgh, however, which otherwise I always hear in my own mental voice as if spelt Edinboro', I am yet forced against my will to hear distinctly the sound of $g$ guttural, as it is natural (and proper) in writing the word Newburgh.

In the same way I have noticed when writing out Monstrum horrendum informe ingens, etc., where elision of the final syllables occurs, I am constrained to hear the elided syllables, while my mental audition of the whole line, when not writing it but reading it to myself, is, of course, as the line would be read, Monstr' horrend' inform' ingens, etc. The auditory imagery is forcibly changed by the supereminence of the written word. Conversely, when writing German words that begin with $s c h$, I generally have to think out each separate letter, because I have not the graphic sign of the equivalent English $s h$ sound well enough organized. The $s h$ sound is to me, in itself, neither English nor German. When written I judge it by my eye as it were for its English or German qualities. I might here say that this applies only to writing in Roman script. When writing the German script which I originally learned, the three German letters $s c h$ are written as a whole and from the sound.

During the time when I studied stenography I noticed in myself a tendency to spell phonetically $(e . g .$, fisician for physician) even while writing long hand. 
In copying into my bibliography the title of an article"Ribot, Recherches, etc., Rev. Phil. 38, 376-40r."-I am positive that my memory image from which I copied the $40 \mathrm{r}$, after looking away from the page of the Psychological Index to the page in my notebook, was purely auditory excepting the just noticeable labio-motor. So foreign was the look of the number to my mind that I reassured myself that the $40 \mathrm{I}$ in $\mathrm{my}$ own handwriting was correct only by comparing the memory image of the auditory mental image of the printed ' $40 \mathrm{Or}$ ' with the auditory image of the 'four hundred and one' in my mind's ear. And, besides, if I had a visual image (subsequently translated into auditory terms) it might have been translated into 'four hundred and first.' That it was definitely ' four hundred and one' seems to be external proof that the imagery was auditory.

It would seem probable that a word exists in the minds of all persons (though I have much testimony to the contrary) as an auditory motor image rather than as a visual image, ${ }^{1}$ for the auditory existence of a word is the primary one (in point of evolution) and it is the only one common to all the others.

Thus if we (I) read aloud we have the words, (a) visually, '4OI'; (b) as auditory imagery (four hundred and one) ; motor, IIII. If (2) we speak words of our own we have auditory and motor imagery, and (3) if we think them we have auditory (some say motor) imagery.

If we (4) hear them we have auditory mental imagery (possibly also motor and visual).

If we read to ourselves (5) we have auditory ( + motor?).

If we copy (6), the imagery is largely auditory.

In all these cases the auditory is present. For myself the auditory element plays the greater part in all of them with the possible exception of No. 2, where in conversation the imagery is little, if at all, attended to. As the auditory imagery is the only element common to all these verbal functions it seems to be collectively the most important element. Individually it may differ, i.e., different people probably have it in different proportions, but the true word is auditory alone. It is the heard word

${ }^{1}$ James cites a good case of the latter, Psychology Vol. II., p. 57 . 
or the spoken word, and all other forms of it are but faint and unmeaning copies of it.

Now if we copy words from print into our own handwriting it seems that the simplest and easiest way to write them is to copy either from the visual or from the auditory imagery. The graphomotor imagery, in copying from printed matter, I could not conceive. If the visual imagery is copied, there is an actual visual perception and a visual imagery in conflict, at any rate unnecessarily duplicating each other.

To retain long phrases thus in a purely visual way, even for so short a time as a few seconds, seems to me impossible. My visual memory image and my visual mental imagery has never had such minute definition as to reproduce individual words, or even single letters, in ordinary pica type. So that, in copying from my memory image, it is the auditory and not the visual which I use. With this I can hold for a short time as a unit several phrases without confusion, e.g., "Liberty and union, now and forever, one and inseparable."

\section{Historical Note on the Psychological Description of Mental Imagery.}

Literature, both artistic and philosophical, contains many references to and observations upon the imagination, the phantasy and the reproduction of sensations, from the time of Aristotle, who said that imagination is the movement which results upon actual sensation. ${ }^{1}$

But it is only in the latter half of the nineteenth century that it has been studied as an object of purely psychological research and not as imagination or poetry.

Much of the study of the processes of association has come more or less near to the investigation of mental imagery, but the associations collected were, of course, but words, and they were arranged according to verbal categories, $e . g$. , no attention is paid to the sense elements in which the associations water-pail, candle-stick, etc., take place, and in such reports all that has been given is the mere words and not taste of muddy water;

1 De Anima, III., 3, 429a I. 
smell of new wooden pail ; touch of brass candle-stick ; appearance of wax candle, etc.

In the same direction have been the many investigations of the laws of memory. The psychologist's attention, however, in all these cases bas been given almost entirely to explain why, on the one hand, certain things, words, etc., were remembered and why certain others were not. At most a brief 'note' is subjoined or ' remarks on the experiments' in which the subjects tell how they have happened to think of their various thoughts.

Thus, even in so recent an experiment as Binet and Henri's ${ }^{1}$ on the memory of words and the memory of phrases, though the manner of recall was noticed it was only slightly noticed and was not studied at all. One of their subjects says the words were suggested to him partly by auditory image.

It is true, of course, that what was being studied in these papers was not the mental imagery, but was memory and association. But the fact that any observation of the modes of the mental imagery was made shows an appreciation of the interest of the study of mental imagery.

In I843 appeared Myer's Untersuchung über die physiologie der Nervenfaser, with the now famous record of the author's subjectively produced after image, and in I 860 Fechner's $P_{s y-}$ chophysik continuing the comparison between mental imagery and after images. ${ }^{2}$

In 1879 Francis Galton published an article on 'Generic Images' ${ }^{3}$ in which he tried to show that they were formed like composite photographs, by superposition on the brain of impression after impression from the sense of sight. This was followed in the next year by the article 'Mental Imagery, ${ }^{\text {" }}$ in which he suggested that there might be individual differences in this faculty and added to the sense of sight the other senses as likely to afford images analogous to the pictures called up in the visual imagination.

In the same year Professor Stricker of Vienna wrote ${ }^{5}$ that

1 Année Psychologique, I., 23 (1894).

'See James' Psychology, II., 5o.

${ }^{3}$ Nineteenth Century Magazine.

4 Fortnightly Review.

${ }^{5}$ Studien über die Sprachvorstellungen. 
his thinking in words was accompanied by a feeling in the throat and lips as of suppressed articulation, which he compared to a piano player's running his fingers over the keys of his instrument, but touching them so lightly as to make no sound on the strings.

In $\mathrm{r} 88 \mathrm{I}$ Galton published an article on the "Visions of Sane Persons." In this he showed that five per cent. of the persons that he had examined were exceedingly vivid visualizers to the extent of having number forms.

Books dealing directly with mental imagery are to be divided into: (I) systematic treatises and (2) reports on experiments (subjective or objective), and each of these might again be subdivided into those which concern mental imagery as a whole and those treating of only a part of our mental imagery, viz. : word imagery.

I find no systematic treatise upon mental imagery as a whole.

Three books concerning the mental imagery of words are to be mentioned, those of Stricker, ${ }^{2}$ Egger $^{3}$ and Ballet. ${ }^{4}$

Ballet describes in turn mental audition and vision (sensory) and mental imagery of speaking and writing (motor) from the point of view of aphasia. He cites many individual observations, but only with regard to word imagery.

The works of Egger and Stricker make an interesting contrast and illustrate a psychological misunderstanding which it took some time to explain.

Egger gives an exhaustive analysis of the word imagery from an auditory point of view, comparing his internal speech with the real sound of external speech. He says the faintest external utterance is still a sound far louder than even the loudest internal speech, and adds " $m y$ internal speech is the imitation of $m y$ voice, in timbre, intensity, peculiarities of intonation, etc. It is a simple auditory image without tactile imagery." He recognizes the other imageries, too, dividing them into: (I) images in the strict sense of the word or visual images; (2) in-

1 Fortnightly Review.

2 Op. cit.

${ }^{3}$ La parole interieure, Paris, $188 \mathrm{r}$.

- Le Langage interieure, Paris, 1888. 
ternal sounds which include words as well, and (3) imageries of the other senses, smell, taste, touch, organic, muscular.

Stricker, in his already mentioned book, on the other hand, not only confines himself to words and the description of the mental existence of words, but sees in himself only the motor side of them. And, in addition to that, he has unfortunately been misunderstood to affirm that but one side existed. His motor imagery apparently predominates in all his thought and in his Studien $^{1}$ he describes very carefully his word imagery as principally the sensation of innervation of his lip and tongue and throat muscles. He says with the idea (Vorstellung) of every sound (Laut) is inseparably bound a (more or less distinct) feeling in the organs of speech. These feelings are situated in the muscles, and are similar to those experienced when we really speak the word out loud." Again, "The expression 'sound, (Laut) is a misnomer; it implies an idea of audition which is not included in the pure idea of words. ${ }^{2}$

It seems that we must accept the views both of Stricker and of Egger contradictory as, at first sight, they appear. The latter says his internal speech is auditory imagery, and he is right. The former says his internal speech is articulatory-motor, and he is right.

Other writers do not stop there, however. They say to each, "You are deceiving yourself." Although Messrs. Stricker and Dodge $^{3}$ say they fail to imagine sound at all save by the rapidly vanishing memory image, and though I should say that I fail to detect any but the very slightest feeling of innervation or of muscular action or vibration in any of the organs of speech, when, in thinking silently, I look for such imagery, yet the answer will be made that the other elements are there, though they may not yet have crossed the threshold of consciousness.

Thus Netter says 4 that even visualizers, though they do not know it, must be auditory in matter of parole interieure; and

${ }^{1}$ Op. cit., p. I5.

2 "Der Ausdruck 'Laut' wird zwar jetzt nicht mehr ganz passend erscheinen; er weist auf eine Schallvorstellung hin, die ja in der reinen Vorstellung der Worte nicht enthalten ist," p. 27.

${ }^{3}$ See below, p. 52.

- La parole interieure et l'áme, Paris, I892, 
Féré ${ }^{1}$ draws his conclusions as follows : He was preparing a report of an autopsy and wrote poumon 3 for poumon droit. He says: The motions of the hands used to write the figure 3 and the word droit have no similarity, but the motions necessary for the articulation of the words trois and droit have much similarity. So it seems that this lapsus calami was in reality a lapsus linguse betrayed by writing. This shows that the mental representation of an articulate sound is accompanied by motions of the muscles specially used in articulation, and that when we represent the sound in writing we write primarily from the tongue. He adds that he cannot mentally represent an articulate sound (by which I understand the tones of the human voice) without some 'sensations musculaires' in the speech muscles. Nevertheless, when he writes he perceives no motions in the tongue or lips, but believes that his mistake in writing shows that they exist in him.

To me it would appear just as likely that, instead of an articulatory motor center being active together with the graphomotor center, an auditory center (sensory) should guide and direct the pen. A constant motor activity not discharging into objective movement seems, to one who can hear in his mind's ear, a waste of energy. If it is true, however, as Höffding and Erdmann ${ }^{2}$ mention, that excessive thinking in some persons so agitates the nerves of the throat as to make them hoarse ; it is better to report it than to deduce it.

To say that I think in terms of speech-motor imagery, but that I am unconscious of it, contradicts completely my notions of 'type.' For to be auditory in type means not that our mental ear is good and at the same time we do not know it, but when we take occasion to inspect our internal speech, we find that by all the ear-marks we can positively recognize it as auditory. Such 'ear-marks' are the unexpected qualities of timbre which the word imagery sometimes exhibits.

Professor Baldwin contributes an interesting introspection into word imagery in his article on 'Internal Speech and Song.' 3

'A propos d' une Lapsus Calami, Revue Philosophique, Vol. 21, p. 546.

2Psychologische Briefe, No. 15. Cited by Stricker.

Philosophical Review, Vol. II., p. $3^{85}$. 
He says: "We recognize and understand words which we are unable to pronounce aid which we have never written; this recognition must be by and of visual or auditory images. The part played by the visual and motor memories, respectively, in my own case, is seen in the fact that, when I wish to speak in any language but English, the German words come first into my mind; but when I sit down to write in a foreign language, French words invariably present themselves. This means that my German is speech motor and auditory, having been learned conversationally in Germany, while the French, which was acquired in school by reading and exercise writing, is visual and hand motor." 1

One of the most recent works on the subject of word imagery is that of Raymond Dodge. ${ }^{2} \mathrm{He}$ has gone even further than Stricker in the description of these mental phenomena. He imagines words to be spoken by himself and almost invariably without auditory imagery. He gives an elaborate analysis of his motor imagery of all the letters of the English alphabet and in a table compares his own with those of Stricker.

Beaunis ${ }^{3}$ includes some observations upon the word imagery under the name of sensations du pensée. The sensations internes are all the sensations which come to us in ways other than 'the five senses.' They are organic sensations, wants or desires for action or inaction of the various organs and muscles, and sensations which the various functions of the body give us, emotional sensations and those of a peculiar nature not included in the others. These are the sense of orientation, the magnetic sense, the meteorologic or weather sense, the sense of duration, the sense of thought, and, finally, all the pleasures and pains. As illustration of the 'sense of thought' he cites that Blake, the English artist and poet, thus called up the illustrious dead and conversed with them, soul to soul. It is surprising that he should have included word imagery and not from it passed on to other auditory-motor, then purely auditory and visual imagery, and so on.

\footnotetext{
${ }^{1}$ Baldwin also cites Ballet, op. cit., p. 62.

${ }^{2}$ Die Motorischen Wortvorstellungen, Halle, 1896.

${ }^{3}$ In Les Sensations Internes (1889).
} 
The majority of the articles are reports upon investigations of the questionnaire type.

Thus Stetson and Armstrong, in articles in the Psychological Review, have continued with Galton's questions and with college students as subjects.

In I89r Ribot in his Enquête sur les idées générales ${ }^{1}$ reported that he had orally questioned ro3 people and found that what was immediately suggested to them when they heard some general term such as animal, form, justice, relation, was (I) a concrete, visual or motor mental imagery or (2) a written or printed word or (3) a mental image of sound or articulation, sometimes both. His results, namely that about $50 \%$ of his subjects thought of ' nothing,' when abstract terms like ' cause,' 'justice,' etc., were mentioned, have been criticized as of doubtful importance. It seems to me, however, that the persons who frankly confessed to nothing probably had nothing (as I have myself many times), but the words, because there is nothing in those words which can arouse appropriate and distinctive mental imagery.

In 1895 Dugas, in an article, Recherches experimentales sur les differents types d' images ${ }^{2}$ reports that he succeeded in getting ten persons to tell him what sense imagery was aroused by the words sugar, lemon, tobacco, heliotrope, wet sponge, sawing marble, etc. He regards the sense imagery, however, as the least important of the facts recorded by him.

A new note is struck by Paul Tannery. His introspection into his own mental language shows him that he has articulatory motor images when writing. He notes, however, that the word imagery does not accompany the words as they are written or spoken, but it precedes them, and, further, that the will seems to have little to do with what we say. Thus, ${ }^{3}$ we hear ourselves speaking and we are satisfied or dissatisfied with what we have said. If we are dissatisfied, the mind interposes to make corrections. But aside from that the will plays no rôle, except that of regulating the intensity of the voice.

\footnotetext{
${ }^{1}$ Revue Philosophique, Vol. 32, p. $3^{82}$.

1 Revue Philosophique, Vol. 39, p. 285.

${ }^{3}$ Sur la parole interieure, Revue Philosophique, 1887 .
} 


\section{SUPPLEMENTARY.}

I have now mentioned five different methods of studying mental imagery. The results gained by Experiments A and B are, in my opinion, valuable only if we bear in mind the novelty of the subject and the very meagre data which we have upon this point. Galton found that many scientific men had no visual imagery. (Does this imply no tactile, auditory, etc.?) The difficulty of getting trustworthy data by the questionnaire method is in many cases unsurmountable. The misunderstandings are numerous. One gentleman of acute mind and great learning could not imagine pictures of senses other than sight, for only sight is pictorial.

The results of Experiments $\mathrm{C}$ and D indicate a profitable path for finer and more scientific literary criticism. The analysis into sense content of any literary work should, by rights, take note of the borderland between the mental imagery of the five senses and that of the emotions and other internal feelings.

Experiment E, in which I have tried to analyze my own mental imagery, including word-imagery, may serve as a further comment upon and an elucidation of the difference in type of internal speech, first brought out in the discussion between Stricker and his adversaries. I hope it will also indicate some possibilities in training our introspection in the direction of careful observation of conscious mental states.

The value of conscious ${ }^{1}$ mental imagery seems, to some, a matter of doubt. I can only say that to me it is a source of great pleasure, and in word thinking a sine qua non. There is a deeprooted prejudice, however, against anything containing much of sense elements-witness the unfortunate tinge which the words sensation, sensuous, sensual, etc., have. On the other hand the training of the various sense imageries has been advocated by R. P. Halleck, ${ }^{2}$ who advises that all the imageries of children be cultivated before the impressionable age is past. We realize, however, that it would be impossible to prove that a vivid imagery in later life was the result of training or had the

1 Not that there is unconscious mental imagery, but simply to emphasize that consciousness is essential.

${ }^{2}$ The Education of the Central Nervous System, New York, 1896. 
slightest cause in the conscious cultivation of that faculty in youth.

The most potent argument for a training of our sensory imagery is to me that we realize by imagery, and by imagery alone, the meaning of words, whether the words be abstract or concrete.

I will here barely mention that of which a full consideration would take too long to accomplish, and would, I think, belong more to a complete treatise on psychology than to this brief research.

The effect of the mental imagery upon the sensations may be seen, not in the comparison of a past with a present sensation, as, for instance, the size of one square of yellow paper which I saw yesterday with the one I have before me to-day, but in the strong emotional tone which, I observe, the mental imagery imparts to the sensations which I receive, while I am receiving them. The mental images which crowd upon me when listening to music or to a stirring address are those of all the five senses and of emotion too, and they in turn arouse real and present emotions which exhibit themselves physically. It is the rhetorical figure 'vision' which the orator employs to fire his audience to action and in this sense 'vision' does not exclude the imagery of the other senses. It is chiefly visual elements which compose my mental imagery while listening to Beethoven's Pastoral Symphony, while all the others contribute; for there is not only the sight of the trees of the forest with patches of sunlight, but the soft, cool, moist touch of the moss, the pleasant warmth of the sun, the fragrance of the leaf mold and fresh air of the stream and the oppression of the atmosphere before the storm.

I have found that what the mental imagery brings to the sensation produces the effect of two sensations at once. The half hidden, the 'suggestive,' is, too, much more potent than what is entirely laid bare. "The modest charm of not too much, part seen, imagined part." I seem to have an increased power, or the emotions which crescent power produces, when I see through or behind any thought fabric or philosophical integument.

The metaphor and simile in literature put one mental image 
before the other so that, as it were, we see both at once, $e . g$., "Now lies the earth all Danaë to the stars." I think that in this alone we derive our chief pleasure, not from the fact that Tennyson has here expressed an original thought in beautiful language, but from the visual imagery of the stars as a shower of gold into which Jupiter transformed himself.

I will instance only the following as what appropriate mental imagery, and only that, can make comprehensible :

'Mid flowers fair-heaped there stood a bowl

With water. She therein

Through eddying bubbles slid a cup

And offered it, being risen up,

Close to her sister's mouth to sup.-Rossetti's Bride's Prelude.

This very good example of the visual element in the painterpoet's literary work calls for a very vivid visualization on the part of the reader to make it beautiful to him.

A Belgian writer, Paul de Reul, thus develops the mental imagery in the following lines from Rossetti's Jenny:

Lazy, lanquid, laughing Jenny,

Fond of a kiss and fond of a guinea.

He says of this: "Le retour des mêmes consonnes est euphonique; il est en suite expressif, car le $L$ exprime la voluptueuse langueur, le $F$ nous fait voir deux levres se tendant pour un baiser, le quel devient audible dans 'kiss."'

If it be true that the arousing of vivid mental image in the mind be of value in our education as an awakening of the finer emotions, as I believe it is, then we have, as psychologists, the greatest possible need to investigate the two following problems which in my present essay could be no more than indicated.

Ist. Is the faculty of imagery susceptible to training? and, if not,

2d. Can we tell by outward signs, by objective experiments, by the questionnaire, oral and written, or by the simple reaction times to various stimuli (of sight, sound, touch, etc.), whether a given person possesses the faculty and in what degree, and in what direction?

'La Langue et le Style, Revue de l' Université de Bruxelles, No. 10. 
I confess that my own experiments upon other persons have as yet given me but little result. I have already mentioned the difficulties I encountered in my questionnaire research (see p. 7) among college students, among artists and in my oral examination of the latter. Words are so spontaneous that what is behind them is often misjudged and prejudice against confessing anything like 'visions' among 'sane persons' tends to conceal truth, and the reverie or undirected play of the imagination is so little respected as to be seldom brought forth to the light of science.

I believe that if the mental imagery is susceptible to training it will appear so in that part of us where we receive most and earliest mental training, viz.: in our reading, writing and arithmetic.

With the realization of the various types of word imagery and a discovery of what they mean we shall be on the road to a better understanding of words, language, philosophy.

Is a single sense imagery of an object generally occupying the stream of consciousness at any given time? Is it always, or only sometimes, a sense complex? If words exclusively filled the stream they might for a long time satisfy, but could they be perpetually adequate? To what extent would we go in relying solely upon words, before our minds should demand some sense imagery content, to correspond to the flight of words? If words mean both words and things, if they represent both words and other mental imagery, then a full realization of this will have to precede a complete and consistent philosophy of life.

Whether words which depart more and more from a meaning, that can be called mental imagery, can be used in philosophy is a question which cannot be discussed here. Philosophy might be solely a word system and yet have a positive value. But that words do depart more and more from a mental imagery meaning and approach nearer and nearer to a flatus vocis is something that, though recognized by one party of linguists, can be fully illustrated only by a thorough research into mental imagery.

That we work as well with the mental imagery as with actual words is shown by the way most persons learn to read a 
foreign language to the exclusion of writing or speaking it. Mr. Babbitt, of the Germanic department of Columbia University, has shown ${ }^{1}$ that one gets a working knowledge of a language sufficiently well by learning to read it.

In learning merely to read a foreign language we are paying more attention to the language itself than to the mental imagery aroused in us by the French, German or Italian, etc., words. To learn the language is something more, viz., to speak it and to write it, which is an accomplishment, like playing the piano, to be acquired if there is time and opportunity. In learning not merely to read the language, but to speak it and to write it, we are learning what we are constantly practicing in our own language-to express the imagery of our own minds in words. This is learning the language; the other is learning foreign imagery.

We realize the difference between languages in respect to mental imagery and appreciate the possibility that their effect even upon philosophical thought has not yet been fully stated. Visualization as a basis of the systems of some English psychologists has been already suggested. ${ }^{2}$ We may find the motor sense as the basis of some of the philosophies.

What may mean the discovery of types in word imagery? Does it, perhaps, indicate that the signification of words may have a motor value, as it were, for some people and a merely auditory value for others? We observe that some people are laconic, others verbose. Possibly strength of argument may seem to the latter to reside in length of sentence and power of innervating the speech muscles in long-continued inundations of syllogisms. We remember the discussions ${ }^{3}$ between Socrates and Protagoras about whether they should talk in short sentences in Socrates' fashion or whether Protagoras should be allowed his long flights of argument. And we remember, too, that Socrates heard the voice of his Dæmon. So, possibly, if

'In a paper entitled 'Common Sense in Teaching Modern Languages, in 'Methods of Teaching Modern Languages.' 2d Ed., Boston, 1897.

2 By A. Fraser. Visualization as a Chief Source of the Psychology of Hobbes, Locke, etc., Am. Jour. Psy., Dec., 1891.

- Protagoras, $334 \mathrm{C}$. 
one is auditory-linguistic he should never enter into an argument with the motor-linguistic person, as, on all topics except the most concrete facts, either will inevitably fail, completely, to understand the other.

The spontaneous quality of our mental imagery is finally to be insisted upon. I can, of course, but refer to the words of Tannery (p. 53) and add to them my own testimony. My mental images come and go as they please, and I cannot persuade myself that $I$ have the least control over them. When I think, the words in which I think come to me. I may be more responsible for the words I speak aloud than for those which come to my mind's ear, for the latter, it would seem, may be either spoken or left unsaid. At any rate, they are, for a time, before a sort of tribunal which judges them for their intellectual and moral worth. Then, if they pass unchallenged by this tribunal they are uttered. This challenge, however, or inhibition comes in the shape sometimes of words such as " it would be better not to say that" sometimes of a feeling of restraint. In either case whether words or feelings the inhibition comes as it were from without. It has no more 'warmth and intimacy' than the other words and feelings. It is not ours any more, therefore, than the other. Neither is ours.

The objectification of these two sets of words has been poetically told by Tennyson in his ' Two Voices.'

The deterministic implication will be obvious, I believe. If our thoughts are not directly under our control much less are our actions.

Further, we might say that the mental images themselves constitute the motives, the springs of action, for all that we do.

The relation of the mental imagery to the idea, in the general sense; the nature of abstract thought (is it emotion imagery?) with a better definition of abstract terms-these are some of the problems which I believe will be elucidated by a better knowledge of the concrete sensory thought processes, through the study of the mental imagery of all the ten types, including wordimagery. 